\title{
1 The evolution of the global selenium cycle: secular trends in Se isotopes and
}

\section{2 abundances}

3

4 E. E. Stüeken ${ }^{1 *}$, R. Buick ${ }^{1}$, A. Bekker ${ }^{2}$, D. Catling ${ }^{1}$, J. Foriel ${ }^{3}$, B. M. Guy ${ }^{4}$, L. C. Kah ${ }^{5}$, H. G.

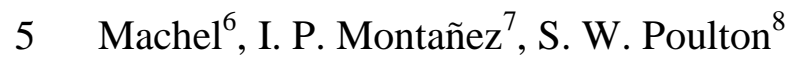

6

7 1. Department of Earth \& Space Sciences and Astrobiology Program, University of Washington,

8 Seattle, WA 98195-1310, USA

9 2. Department of Earth Sciences, University of California, Riverside, CA 92521, USA

10 3. Department of Earth and Planetary Sciences and McDonnell Center for the Space Sciences,

11 Washington University in St. Louis, St. Louis, MI 63130, USA

12 4. Dept. of Geology, University of Johannesburg, Auckland Park 2006, South Africa; Present

13 Address: Mineral Services, SGS South Africa, 58 Melville Street, Booysens, Johannesburg 2091,

14 South Africa

15 5. Department of Earth \& Planetary Sciences, University of Tennessee, Knoxville, TN 37996,

16 USA

17 6. Department of Earth \& Atmospheric Sciences, University of Alberta, Edmonton, Alberta T6G

18 2E3, Canada

19 7. Department of Earth and Planetary Sciences, University of California, Davis, CA 95616, USA

20 8. School of Earth and Environment, University of Leeds, Leeds, LS2 9JT, UK

$21 *$ corresponding author. evast@uw.edu 


\section{Abstract}

The Earth's surface has undergone major transitions in its redox state over the past three

25 billion years, which have affected the mobility and distribution of many elements. Here we use

26 Se isotopic and abundance measurements of marine and non-marine mudrocks to reconstruct the

27 evolution of the biogeochemical Se cycle from $~ 3.2$ Gyr onwards. The six stable isotopes of Se

28 are predominantly fractionated during redox reactions under suboxic conditions, which makes Se

29 a potentially valuable new tool for identifying intermediate steps from an anoxic to a fully

30 oxygenated world. $\delta^{82 / 78}$ Se shows small fractionations of mostly less than $2 \%$ throughout Earth's

31 history and all are mass-dependent within error. In the Archean, especially after 2.7 Gyr, we find

32 an isotopic enrichment in marine $(+0.37 \pm 0.27 \%$ ) relative to non-marine samples $(-0.28 \pm$

$330.67 \%$ ), paired with increasing Se abundances. Student $t$-tests show that these trends are

34 statistically significant. Although we cannot completely rule out the possibility of volcanic Se

35 addition, these trends may indicate the onset of oxidative weathering on land, followed by non-

36 quantitative reduction of Se oxyanions during fluvial transport. The Paleoproterozoic Great

37 Oxidation Event (GOE) is not reflected in the marine $\delta^{82 / 78}$ Se record. However, we find a major

38 inflection in the secular $\delta^{82 / 78}$ Se trend during the Neoproterozoic, from a Precambrian mean of

$39+0.42 \pm 0.45 \%$ to a Phanerozoic mean of $-0.19 \pm 0.59 \%$. This drop probably reflects the

40 oxygenation of the deep ocean at this time, allowing Se oxyanions to be stable throughout the

41 water column. Since then, reduction of Se oxyanions has likely been restricted to anoxic basins

42 and diagenetic environments in sediments. In light of recent $\mathrm{Cr}$ isotope data, it is likely that

43 oxidative weathering before the Neoproterozoic produced Se oxyanions in the intermediate

44 redox state $\mathrm{Se}^{\mathrm{IV}}$, whereas the fully oxidized species $\mathrm{Se}^{\mathrm{VI}}$ became more abundant after the

45 Neoproterozoic rise of atmospheric oxygen. 


\section{Introduction}

Se is an essential micronutrient for many organisms (e.g. Mayland, 1994; Gladyshev, 2012). In natural environments it can be found in four redox states, as $\mathrm{Se}^{\mathrm{VI}}\left(\mathrm{SeO}_{4}{ }^{2-}\right), \mathrm{Se}^{\mathrm{IV}}\left(\mathrm{SeO}_{3}{ }^{2-}\right.$

49 or $\left.\mathrm{HSeO}_{3}{ }^{-}\right), \mathrm{Se}^{0}$, and organic and inorganic $\mathrm{Se}^{-\mathrm{II}}$. In the modern ocean, the oxyanions $\mathrm{Se}^{\mathrm{VI}}$ and

$50 \mathrm{Se}^{\mathrm{IV}}$ are most abundant and show typical nutrient abundance profiles with depletion in the photic

51 zone, replenishment below the photic zone due to organic matter remineralization and constant

52 concentration in the deep ocean (Cutter and Cutter, 2001). Organic Se ${ }^{-I I}$ is common in surface

53 waters but it is almost entirely re-oxidized at depth and thus insignificant below the photic zone.

54 In anoxic water columns, remineralization of organic matter does not occur, such that organic $\mathrm{Se}^{-}$

55 II phases dominate below the chemocline and Se oxyanions remain low throughout the water 56 column (Cutter, 1982; Cutter, 1992). Sediments that formed in anoxic environments therefore 57 mostly contain reduced phases, including $\mathrm{Se}^{0}$ and organic and pyrite-bound $\mathrm{Se}^{-\mathrm{II}}$ (Kulp and Pratt, 58 2004; Fan et al., 2011).

59 The six stable isotopes of Se (masses 82, 80, 78, 77, 76 and 74) are most strongly

60 fractionated during kinetic redox transformations, which favor the lighter masses. In laboratory 61 experiments, abiotic reduction of Se oxyanions to $\mathrm{Se}^{0}$ or $\mathrm{Se}^{-\mathrm{II}}$ with $\mathrm{HCl}, \mathrm{NH}_{2} \mathrm{OH}$, ascorbic acid, $62 \mathrm{Fe}^{2+}$ in green rust or sulfide can impart larger negative fractionations $(\varepsilon=10-25 \%$, where $\varepsilon=$ $\left.63 \delta^{82 / 78} \mathrm{Se}_{\text {reactant }}-\delta^{82 / 78} \mathrm{Se}_{\text {product }}\right)$ than biotic reduction $(\varepsilon=6-14 \%$ ) (Krouse and Thode, 1962; Rees

64 and Thode, 1966; Rashid and Krouse, 1985; Johnson et al., 1999; Herbel et al., 2000; Ellis et al., 65 2003; Johnson and Bullen, 2003; Mitchell et al., 2013). However, in natural systems, abiotic 66 reduction is thought to be kinetically inhibited such that biological fractionation likely dominates 67 (Johnson and Bullen, 2004). Large fractionations can also occur during equilibration of Se 68 species with different redox states, where, as in kinetic isotope fractionation, the more oxidized 
69 forms become isotopically enriched by up to 33\% ( $\mathrm{Li}$ and Liu, 2011). Although it has so far not

70 been demonstrated that equilibrium processes are insignificant in natural environments, the

71 dominance of kinetic fractionation in other isotopic systems like $\mathrm{S}$, as well as the co-occurrence

72 of different Se redox species in thermodynamic disequilibrium in natural samples (e.g. Cutter

73 and Bruland, 1984; Kulp and Pratt, 2004) suggests that kinetic processes are most important

74 (reviewed by Johnson and Bullen, 2004). Moderate negative fractionations from $<0.6 \%$ o to $2.6 \%$

75 have been reported for $\mathrm{Se}^{\mathrm{VI}}$ assimilation into biomass (Johnson et al., 1999; Hagiwara, 2000;

76 Clark and Johnson, 2010), but those values greater than $0.6 \%$, which were measured by

77 Hagiwara (2000), have been questioned due to possible fractionation during sample preparation

78 (Johnson and Bullen, 2004). Hence isotopic fractionation associated with assimilation is

79 probably on the order of $0.6 \%$ or less and thus minor. Similarly, $\mathrm{Se}^{\mathrm{IV}}$ adsorption on Fe oxides

80 results in small negative fractionations of up to $0.7 \%$ (average $0.1 \%$ ) (Johnson et al., 1999;

81 Mitchell et al., 2013). Volatilization of organic $\mathrm{Se}^{-\mathrm{II}}$ from incubated soils can impart moderate

82 fractionations of up to 2.7\%o (Johnson et al., 1999; Schilling et al., 2011a), but Se gases have

83 such a short atmospheric residence time of only a few hours (Wen and Carignan, 2007) that this

84 pathway is insignificant over geologic timescales. Consequently, it appears that large Se isotope

85 fractionations of greater than $1 \%$ in geological samples should be evidence of biological

86 reduction of Se oxyanions. As noted by others (Ellis et al., 2003; Johnson, 2004; Johnson and

87 Bullen, 2004), isotopic fractionations associated with oxyanion reduction may be smaller in

88 natural ecosystems than under experimental conditions due to differences in physiology between

89 cultured microorganisms and natural consortia. However, individual reports of fractionations up

90 to 4\%o in some marine shales (Wen et al., 2014; Stüeken et al., submitted) suggest that Se

91 oxyanion reduction can leave a detectable signature in old rocks if it occurred at the time of 
92 deposition. Smaller fractionations associated with oxyanion adsorption and assimilation into

93 biomass may be significant in oxic environments where reduction does not occur. This raises the

94 possibility of using Se isotopes as an independent tool for reconstructing environmental redox

95 changes over Earth's history (Mitchell et al., 2012; Stüeken et al., 2015). Because of its relatively

96 low abundance, multiple redox states and high redox potential (Johnson, 2004), Se may be more

97 sensitive to redox and productivity changes than other proxies, such as S and perhaps Mo. We

98 note that an impediment to this line of research is the current lack of data about Se isotopic

99 fractionations associated with volcanic eruptions, which may have been important in the past, but

100 we will discuss this issue as appropriate.

101 This study is composed of two parts with the aim of reconstructing the evolution of the

102 Se cycle through Earth's history. First, we compile recent marine Se isotope data from the

103 literature and create a working model for how Se isotopes behave on a global scale in the modern

104 ocean under known redox conditions. This will provide a platform for interpreting Se isotope

105 data in deep time. Second, we present new data from mudrocks through time with particular

106 focus on the Precambrian, incorporating transects across environmental gradients in the late

107 Archean and Mesoproterozoic. Combined with existing datasets (Johnson and Bullen, 2004;

108 Rouxel et al., 2004; Mitchell et al., 2012; Layton-Matthews et al., 2013; Wen et al., 2014;

109 Stïeken et al., 2015), this provides us with a record spanning the last 3.2 billion years, i.e.

110 through the proposed Paleoproterozoic and Neoproterozoic oxidation events (reviewed by Lyons

111 et al., 2014a). Both of these events could have affected the Se biogeochemical cycle, and hence

112 the sedimentary Se record may provide independent evidence or additional information on them.

113 More specifically, we test the following hypotheses: (1) Because the most mobile Se species Se $\mathrm{IV}^{\mathrm{IV}}$

114 and in particular $\mathrm{Se}^{\mathrm{VI}}$ are only stable under suboxic to oxic conditions, we would expect that the 
115 marine Se cycle changed profoundly with the oxygenation of the deep ocean in the

116 Neoproterozoic (Canfield et al., 2007; Canfield et al., 2008; Shields-Zhou and Och, 2011; Sahoo

117 et al., 2012). $\mathrm{Se}^{\mathrm{VI}}$ and $\mathrm{Se}^{\mathrm{IV}}$ should have become more stable ions in the water column, i.e. they

118 should no longer have been subject to quantitative reduction, leading to larger net isotopic

119 fractionations preserved in sediments. Hence, we expect to see a systematic difference in isotopic

120 values before and after the Neoproterozoic oxidation event. (2) The high redox potential of Se

121 oxyanions ( $\mathrm{Se}^{\mathrm{IV} / \mathrm{VI}}$ ) compared to sulfate $\left(\mathrm{S}^{\mathrm{VI}}\right)$ (Johnson, 2004) may also have delayed the onset of

122 the Se weathering flux from land into the ocean during the early stages of Earth surface

123 oxygenation. Total S (TS) abundances in marine sediments increased in the late Archean,

124 suggesting incipient oxidative weathering of sulfide minerals, enhanced by microbial activity

125 (Stüeken et al., 2012). If conditions were not oxidizing enough for Se, then TS/TSe ratios in

126 sediments should have been elevated for some time interval afterwards, perhaps until the

127 Paleoproterozoic or Neoproterozoic oxidation events, when atmospheric oxygen levels rose

128 globally. If, however, microbial activity led to locally high redox states sufficient for Se

129 oxidation, then the $\mathrm{Se}^{\mathrm{IV}}$ and/or $\mathrm{Se}^{\mathrm{VI}}$ flux to the ocean may have increased concurrently with the

$130 \mathrm{~S}^{\mathrm{VI}}$ flux and TS/TSe ratios should be constant through time. Hence marine TS/TSe ratios may

131 serve as an indirect proxy for non-marine redox processes. We would further expect to see

132 isotopic differences between non-marine, shallow marine and deeper marine sediments if $\mathrm{Se}^{\text {IV/VI }}$

133 stability and abundance decreased from oxic terrestrial habitats to anoxic seawater.

135 2. Methods

136 2.1. Compilation of recent data 
138 representing the last $500 \mathrm{kyr}$ during which the ocean redox state is relatively well constrained.

139 Included are data from the mid-Atlantic (Johnson and Bullen, 2004), the Bermuda Rise (Shore, 140 2010), the Cariaco Basin (Shore, 2010), the Arabian Sea (Mitchell et al., 2012) and the Black

141 Sea (Johnson and Bullen, 2004; Mitchell et al., 2012). The data set was divided into two

142 categories: open oxic ocean and restricted anoxic basins. Data from the mid-Atlantic, the 143 Bermuda Rise, the Arabian Sea, and from the glacial oxygenated stages of the Cariaco Basin

144 (Shore, 2010) were included in the oxic ocean category. Samples from the Arabian Sea include 145 sediments that formed below an oxygen minimum zone (Mitchell et al., 2012), but because the 146 Arabian Sea rapidly exchanges water masses with the open ocean by upwelling and therefore

147 likely has a high supply of Se oxyanions, it is more similar to an oxic ocean. The restricted 148 anoxic basin category includes data from the interglacial Cariaco Basin (Shore, 2010) and the 149 Black Sea. Although some samples from the Black Sea have been described as oxic (Mitchell et 150 al., 2012), euxinic conditions in the deeper water column probably result in low Se oxyanion 151 concentrations and a short residence time throughout the basin (Cutter, 1992). Therefore, we 152 assigned all Black Sea samples to the anoxic restricted basin category.

\section{2.2. New analyses of ancient rocks}

155 Our new analyses focused on whole-rock samples of kerogenous mudrocks (Table 1), 156 because they are relatively abundant and Se-rich. This approach has the disadvantage that 157 mudrocks can contain multiple isotopically distinct Se phases including elemental $\mathrm{Se}^{0}, \mathrm{Se}^{-\mathrm{II}}$

158 bound to organic matter or substituting for $\mathrm{S}^{-\mathrm{II}}$ in sulfide minerals, and $\mathrm{Se}^{\mathrm{IV}}$ adsorbed to mineral 159 surfaces or kerogen (Kulp and Pratt, 2004; Fan et al., 2011; Schilling et al., 2014b; Stüeken et al., 
160 submitted). Combining these phases probably reduces the measured isotopic range and might

161 make it more difficult to discern patterns. In some ways, this is analogous to measuring trends in

$162 \mathrm{C}$ isotopes without separating organic $\mathrm{C}$ from carbonate. However, separation techniques for

163 differing Se phases in rocks are only beginning to be developed (Kulp and Pratt, 2004; Fan et al.,

164 2011; Schilling et al., 2014b; Stuieken et al., submitted), and it is uncertain if they are useful for

165 ancient samples where isotopic ratios may have re-equilibrated. An alternative approach may be

166 to analyze banded iron formations (BIF) that primarily contain just one phase, i.e. adsorbed $\mathrm{Se}^{\mathrm{IV}}$

167 (Schilling et al., 2014b; Schirmer et al., 2014). However, the Se concentrations in such rocks are

168 very low, presenting analytical difficulties, and BIF or equivalent deep-marine Fe oxides are not

169 available from all time periods or from all environments. Mudrocks have formed throughout

170 Earth's history in a diversity of environments including lakes, tidal flats and outer marine shelves,

171 which allows us to compile data across both the Paleoproterozoic and the Neoproterozoic

172 oxidation events (Lyons et al., 2014a) and to reconstruct environmental redox gradients.

173 One of our principal goals in this study was to determine if mass-independent

174 fractionation of selenium isotopes (MIF-Se) occurred early in Earth's history, analogous to the

175 Archean MIF anomaly seen in quadruple sulfur isotope studies. In order to assess this, we used a

176 sample-standard bracketing analytical protocol rather than the more usual double-spike

177 procedure. We measured all masses from 71 to 84 to allow post-analytical data correction for the

178 full range of possible isobaric interferences without the assumption of strict mass-dependent

179 fractionation (Stüeken et al., 2013). This procedure allows reproducible measurement of 5

180 selenium isotopes, the precise determination of 4 isotopic ratios to less than $0.2 \%$ for $\delta^{76}{ }^{78} \mathrm{Se}$,

$181 \quad \delta^{77} f^{78} \mathrm{Se}$ and $\delta^{82} /^{78} \mathrm{Se}$ and $0.5 \%$ for $\delta^{74} /^{78} \mathrm{Se}$, and thus accurate detection of mass-independent

182 fractionation on three-isotope diagrams (Stüeken et al., 2013). Moreover, natural mass- 
183 independent fractionation in the sulfur and mercury isotopic systems is best expressed by the

184 least abundant and odd-numbered masses (Farquhar et al., 2007; Gosh et al., 2008), which in the

185 case of selenium are ${ }^{74} \mathrm{Se}$ and ${ }^{77} \mathrm{Se}$, both isotopes that are often sacrificed in double-spike

186 methodologies. Our technique has been successfully used to detect small but significant Se

187 isotopic excursions at the Archean-Proterozoic boundary (Stiueken et al., 2013).

188 Our sample preparation methods, analytical protocols and interference corrections for Se

189 isotopes are described in more detail in Stüeken et al. (2013). In brief, rock powders were

190 digested with $\mathrm{HF}, \mathrm{HNO}_{3}$ and $\mathrm{HClO}_{4}$; the Se was extracted by column filtration through thiol

191 cotton fibers and further purified with aqua regia. Analyses were carried out with a hydride-

192 generator (HGX-200) coupled to a multi-collector inductively-coupled plasma mass

193 spectrometer (Nu Instruments). Instrumental mass bias was corrected by standard-sample

194 bracketing. Isobaric interferences, most importantly by argon dimers, arsenic hydrides and

195 germanium, were corrected post-analytically (Stüeken et al., 2013). Results are reported in

196 standard delta notation relative to NIST SRM 3149. Unless noted otherwise, we used the

$197 \quad{ }^{82} \mathrm{Se} /{ }^{78} \mathrm{Se}$ ratio:

$$
\left.\delta^{82 / 78} \mathrm{Se}=\left[\left({ }^{82} \mathrm{Se} /{ }^{78} \mathrm{Se}\right)\right)_{\text {sample }} /\left({ }^{82} \mathrm{Se} /{ }^{78} \mathrm{Se}\right)_{\mathrm{SRM}} 3149-1\right] \cdot 1000
$$

199 because with our method this particular isotope pair yields the most accurate and precise

200 measurements. For conversion to $\delta^{82 / 76}$ Se, which has been used by other laboratories, values can

201 be multiplied by 1.54 , because mass-independent fractionation is absent (see below). We

202 analyzed a total of 202 samples and 127 of those in replicates. The average precision $(1 \sigma)$ was

$203 \quad 0.10 \%$ for $\delta^{82 / 78} \mathrm{Se}$ and $1.6 \%$ (relative error) for Se concentrations. Our result for the

204 international reference material SGR-1, processed with the same method, was $+0.05 \pm 0.18 \%$ o

$205(1 \sigma, \mathrm{n}=9)$, which is in good agreement with recently published values (Schilling et al., 2011b; 
Mitchell et al., 2012; Pogge von Strandmann et al., 2014). Data was statistically evaluated using

207 Student's $t$-test and regression analysis.

Total organic $\mathrm{C}$ and total $\mathrm{S}$ were analyzed with established methods used routinely in the

209 UW Isolab (Schoepfer et al., 2013; Stüeken, 2013) with precisions of 1\% and 10\%, respectively.

210 For TOC, powders were decarbonated with 6N HCl. S was analyzed on untreated samples.

211 Analyses were carried out by flash combustion with an elemental analyzer (Costech ECS 4010)

212 coupled to a continuous-flow isotope-ratio mass spectrometer (Finnigan MAT 253).

213 Statistical comparisons between binned time intervals were carried out using Student's $t$ -

214 test. These methods have sufficient power to detect small but significant shifts in mean isotopic

215 values through time and have been used to detect secular changes in other isotopic systems (e.g.

216 Stüeken et al., 2012). Bins for statistical tests were chosen following previously noted transitions

217 in sulfur (Stüeken et al., 2012) and selenium cycling (Large et al., 2014) in the late Archean and

218 Neoproterozoic, respectively. We further tested for changes around the Paleoproterozoic Great

219 Oxidation Event (Bekker et al., 2004; Anbar et al., 2007; Stuieken et al., 2015).

\section{3. Results}

\section{3.1. Trends in the modern ocean}

223 The compilation of published Se isotope data from marine sediments deposited over the 224 last $500 \mathrm{kyr}$ (Fig. 1) shows that sediments deposited from the open oxic ocean tend to have a 225 slightly but statistically significantly lighter isotopic composition $\left(\delta^{82 / 78} \mathrm{Se}_{\mathrm{avg}}=-0.10 \pm 0.21 \%\right.$, 226 range $-0.90 \%$ to $+0.41 \%$ o $)$ than sediments formed under anoxic water in restricted basins $(+0.07$ $227 \pm 0.24 \%$, range $-0.41 \%$ to $+0.59 \%$; pone-tailed $\left._{<} 10^{-4}\right)$. Sediments deposited in anoxic basins thus 228 tend to be somewhat closer in composition to Se oxyanions ( $\left.\mathrm{Se}^{\mathrm{IV} / \mathrm{VI}}\right)$ dissolved in the open ocean 
$229\left(\geq+0.3 \%\right.$, Rouxel et al., 2004; Mitchell et al., 2012). The isotopic composition of Se ${ }^{\mathrm{VI}}$ and $\mathrm{Se}^{\mathrm{IV}}$

230 dissolved in seawater has not yet been measured directly, but as noted by Mitchell et al. (2012),

231 measurements of $\mathrm{Se}^{\mathrm{IV}}$ adsorbed onto Fe-Mn nodules $(+0.32 \%$, $\mathrm{n}=1$, Rouxel et al., 2004) as

232 well as the composition of phytoplankton $(+0.27 \%, \mathrm{n}=1$, Mitchell et al., 2012) provide lower

233 limits. If adsorption of $\mathrm{Se}^{\mathrm{IV}}$ is associated with a fractionation of $0.1 \%$ on average (Mitchell et al.,

234 2013), then dissolved $\mathrm{Se}^{\mathrm{IV}}$ may have a composition of around $+0.4 \%$. Although assimilation of

$235 \mathrm{Se}^{\mathrm{IV} / \mathrm{VI}}$ into biomass has a fractionation of $0.6 \%$ (Clark and Johnson, 2010), this fractionation

236 may not be expressed if assimilation is quantitative in the photic zone, where Se oxyanion

237 concentrations are depleted (Cutter and Bruland, 1984; Cutter and Cutter, 2001). Hence the

238 composition of phytoplankton (+0.27\%, Mitchell et al., 2012) may approximate that of

239 dissolved $\mathrm{Se}^{\mathrm{IV} / \mathrm{VI}}$. But given the maximum observed fractionations during adsorption and

240 assimilation, dissolved Se oxyanions may be as heavy as $+1 \%$. $\mathrm{Se}^{\mathrm{IV}}$ and $\mathrm{Se}^{\mathrm{VI}}$ are probably

241 isotopically homogenized, because $\mathrm{Se}^{\mathrm{IV}}$ is mostly generated through remineralization of organic

242 matter (Cutter and Bruland, 1984), which does not impart an isotopic fractionation (Johnson and

243 Bullen, 2004).

244 Today, under a fully oxic atmosphere, the input of Se to the ocean from crustal

245 weathering and volcanism probably has an average composition equivalent to that of the crust at

$246+0.01 \pm 0.49 \%$ o (Rouxel et al., 2002), because oxidation as during weathering does not cause

247 isotopic fractionations (Johnson et al., 1999) and normal Se-poor soils are unfractionated relative

248 to crust (Schilling et al., 2011b). As meteorites show approximately the same value $(+0.11 \pm$

$2490.34 \%$, Rouxel et al., 2002), it is unlikely that on a global scale the Se isotope composition of

250 the upper crust has changed much throughout Earth's history. If so, then our compilation

251 suggests that sediments from the modern oxic ocean are systematically depleted relative to the 
252 crustal source whereas dissolved $\mathrm{Se}^{\mathrm{IV} / \mathrm{VI}}$ is enriched. Sediments from anoxic basins are slightly 253 heavier than the crust, but still somewhat lighter than the presumed composition of seawater.

\subsection{New data from ancient sedimentary rocks}

All our new Se isotope data (Table A1) plot within error along the theoretical mass-

257 dependent fractionation line (Fig. 2), indicating that isobaric interferences occurring in the mass 258 spectrometer have been properly corrected. Using our analytical protocol (Stüeken et al., 2013), $259 \delta^{82 / 76} \mathrm{Se}$ is analytically the second most stable ratio after $\delta^{82 / 78} \mathrm{Se}$ (Fig. 2a). $\delta^{82 / 77} \mathrm{Se}$ (Fig. 2b) can

260 be compromised by interferences with ${ }^{77}(\mathrm{ArCl})$ and possibly ${ }^{77}\left(\mathrm{AsH}_{2}\right)$ that are difficult to

261 monitor and to subtract (Stüeken et al., 2013; Stüeken et al., 2015), which probably explains the

262 enhanced scatter in our measurements of this isotopic ratio. $\delta^{78 / 74} \mathrm{Se}$ (Fig. 2c) suffers from

263 interferences with ${ }^{74} \mathrm{Ge}$, magnified by the low abundance of ${ }^{74} \mathrm{Se}$. Occasional outliers in $\delta^{78 / 74} \mathrm{Se}$

264 are thus likely due to improperly corrected residual ${ }^{74} \mathrm{Ge}$. So overall we do not see any evidence 265 of mass-independent fractionation (MIF) in Se at any time in the rock record, in stark contrast to 266 the isotopic record of S (Farquhar et al., 2000). Photochemical reactions involving Se were either 267 not conducive to MIF, or volatile Se compounds were insignificant in relative abundance. It is 268 worth noting that eukaryotic algae, plants and fungi are significant contributors of the major Se 269 gases today, i.e. methylated $\mathrm{Se}^{-\mathrm{II}}$ (e.g. Chasteen and Bentley, 2003), and hence the flux of these 270 gases may have been trivial in the earlier Precambrian prior to the oxygenation of the atmosphere 271 and the radiation of eukaryotic life.

272 Combined with published Se isotope data from the late Archean Mt. McRae Shale

273 (Stüeken et al., 2015) and several Phanerozoic basins (Johnson and Bullen, 2004; Shore, 2010;

274 Mitchell et al., 2012; Wen et al., 2014), our results show that throughout Earth's history (Fig. 3a) 
275 the range of mass-dependent Se isotope fractionation recorded in mudrocks $(-3.1 \%$ to $+2.9 \%)$ is 276 significantly smaller than the 6-25\% measured in oxyanion reduction experiments in the 277 laboratory (Johnson et al., 1999; Herbel et al., 2000; Ellis et al., 2003; Johnson and Bullen, 278 2003), but during most time intervals it exceeds the 0.7\% maximum range expected for Fe-Mn279 oxide adsorption and assimilation into biomass (Johnson et al., 1999; Clark and Johnson, 2010;

280 Mitchell et al., 2013). As discussed above, the relatively small range in bulk sediments is 281 probably in part due to mixing of multiple Se phases recording different isotopic fractionations, 282 but it may also reflect a smaller magnitude in isotopic fractionation under natural, Se-poor 283 conditions.

284 The mean of all new and published isotopic data is $+0.09 \pm 0.59 \%(n=526)$ while the 285 geometric mean of total Se (TSe) concentrations is $1.3+4.8 /-1.0 \mathrm{ppm}\left(=10^{0.12 \pm 0.67} \mathrm{ppm}\right)$. We 286 use the geometric mean here because of the wide TSe range over several orders of magnitude. In 287 the normal marine record (Table 2), isotopic ratios decrease slightly but significantly from the 288 mid-Archean (here 3.19-2.87 Gyr; $+0.62 \pm 0.27 \%$ o, $n=23$, after removing one outlier of $+1.43 \%$ 289 and $2.23 \mathrm{ppm}$ TSe) to the late Archean $(2.71-2.50 \mathrm{Gyr} ;+0.35 \pm 0.39 \%, \mathrm{n}=110)\left(\mathrm{p}_{\text {one-tailed }}=10^{-4}\right)$ 290 but show no major change from the late Archean to the Proterozoic $(2.49-1.10$ Gyr; $+0.45 \pm$ $2910.55 \%, \mathrm{n}=59 ; \mathrm{p}_{\text {one-tailed }}=0.12$ ). The most significant change in Se isotopes occurs between the 292 Proterozoic and the Phanerozoic $\left(0.54\right.$ Gyr to modern; $\left.-0.19 \pm 0.59 \%, \mathrm{n}=240 ; \mathrm{p}_{\text {one-tailed }}=10^{-25}\right)$. 293 Although we do not have any data for samples with ages between 1.10 Gyr and 0.55 Gyr, it is 294 plausible that this isotopic transition coincides with the purported "second rise of oxygen" and 295 the oxygenation of large parts of the deep ocean in the late Neoproterozoic (Canfield et al., 2007; 296 Shields-Zhou and Och, 2011; Sahoo et al., 2012). This hypothesis is supported by recent 
297 evidence for a marked increase in pyrite-bound Se at around $600 \mathrm{Myr}$ (Large et al., 2014), which 298 also suggests a major reorganization in the marine Se cycle around this time.

299 In these compilation of normal marine Se isotopes and abundances, we excluded

300 Phanerozoic basins known to be restricted: the modern Cariaco Basin and Black Sea, the 180

301 Myr Posidonia Shale, the 380 Myr New Albany Shale (total average $\delta^{82 / 78} \mathrm{Se}=+0.23 \pm 0.40 \%$, $\mathrm{n}$

302 = 66) (Johnson and Bullen, 2004; Shore, 2010; Mitchell et al., 2012). These basins show

303 distinctively higher TS/TSe ratios $\left(1.82+3.19 /-1.16=10^{0.26 \pm 0.44}[\% / \mathrm{ppm}], \mathrm{n}=37\right)$ than most

304 other Phanerozoic basins $\left(0.27+0.71 /-0.20=10^{-0.57 \pm 0.56}[\% / \mathrm{ppm}], \mathrm{n}=130 ; \mathrm{p}_{\text {one-tailed }}=10^{-14} ;\right.$ Fig.

3053 3) due to higher TS concentrations. This is probably the result of locally distinct geochemical

306 processes under restricted euxinic conditions, justifying our decision to exclude these basins

307 from the normal marine record. In the Precambrian, the distinction between restricted and open

308 marine basins is less certain. All Precambrian basins sampled for this study have been argued to

309 openly exchange with the ocean, perhaps with the exception of the Belt Basin. But, as discussed

310 in Section 4.5, Se likely had a short residence time in the Precambrian ocean, making the

311 distinction between open and restricted basins unnecessary. We therefore treat all our

312 Precambrian data as representative of normal marine conditions, but discuss environmental

313 differences in more detail below.

314 A highly significant transition in average Se concentrations occurs between the mid-

315 Archean $\left(0.17+0.11 /-0.07 \mathrm{ppm}=10^{-0.76 \pm 0.21} \mathrm{ppm}\right)$ and the late Archean $(1.45+2.75 /-0.95 \mathrm{ppm}=$

$31610^{0.16 \pm 0.46} \mathrm{ppm} ; \mathrm{p}_{\text {one-tailed }}=10^{-23}$ ). Concentrations then decrease slightly from the late Archean to

317 the Proterozoic $\left(0.74+3.73 /-0.62 \mathrm{ppm}=10^{-0.13 \pm 0.78} \mathrm{ppm}\right.$; $\left.\mathrm{p}_{\text {one-tailed }}=0.005\right)$ and increase

318 significantly again from the Proterozoic to the Phanerozoic $\left(1.75+7.42 /-1.42 \mathrm{ppm}=10^{0.24} \pm 0.72\right.$

319 ppm; pone-tailed $=0.0006$ ). 
Marine TS/TSe ratios $[\% / \mathrm{ppm}]$ only show relatively subtle changes through time. They

321 increase from $0.45+0.58 /-0.25\left(=10^{-0.35 \pm 0.36}\right)$ before $2.71 \mathrm{Gyr}$ to $0.78+1.98 /-0.56\left(=10^{-0.11 \pm 0.55}\right)$

322 between 2.71 Gyr and 1.1 Gyr ( $\left.\mathrm{p}_{\text {one-tailed }}=0.04\right)$ with no significant change between the late

323 Archean and the Proterozoic $\left(\mathrm{p}_{\text {one-tailed }}=0.42\right.$ ). They then decrease significantly to $0.17+0.69 /-$

$0.13\left(=10^{-0.78 \pm 0.71}\right)$ in the Phanerozoic $\left(\mathrm{p}_{\text {one-tailed }}=10^{-17}\right)$.

A few sites further show environmental gradients in Se isotopes:

- In the mid-Archean Witwatersrand Supergroup (Fig. 4a) from South Africa (2.96-2.87 Gyr),

327 all samples are isotopically positive, but fluvial samples are slightly lighter $\left(\delta^{82 / 78} \mathrm{Se}=+0.30 \pm\right.$

$3280.19 \%, \mathrm{n}=5)$ than proximal marine samples $\left(\delta^{82 / 78} \mathrm{Se}=+0.74 \pm 0.28 \%\right.$, $\left.\mathrm{n}=8\right)\left(\mathrm{p}_{\text {one-tailed }}<0.01\right)$.

329 Distal marine samples are variable $\left(\delta^{82 / 78} \mathrm{Se}=+0.63 \pm 0.51 \% \mathrm{n}, \mathrm{n}=5\right)$. In general, marine shelf

330 samples from the Witwatersrand Supergroup agree well with upper continental slope samples

331 from the Soanesville Group in Western Australia (3.2 Gyr; $\delta^{82 / 78} \mathrm{Se}=+0.64 \pm 0.18 \%$, $\mathrm{n}=9$ ).

332 - In the late Archean Fortescue Group (Fig. 4b) in Western Australia (2.75-2.65 Gyr), we find a

333 significant contrast between marine environments $\left(\delta^{82 / 78} \mathrm{Se}=+0.37 \pm 0.27 \%, \mathrm{n}=28\right)$ and non-

334 marine environments $\left(\delta^{82 / 78} \mathrm{Se}=-0.28 \pm 0.67 \%, \mathrm{n}=19\right)\left(\mathrm{p}_{\text {one-tailed }}<0.001\right)$. Shallow marine

335 shales from the Carawine Dolomite $\left(\delta^{82 / 78} \mathrm{Se}=+0.32 \pm 0.12 \%, \mathrm{n}=7\right)$ are on average the same as

336 deeper marine samples from the Jeerinah Formation $\left(\delta^{82 / 78} \mathrm{Se}=+0.38 \pm 0.30 \%, \mathrm{n}=21\right)$ but less

337 variable. Both agree well with marine samples from the Ghaap Group in South Africa (2.56-2.52

338 Gyr; $\left.\delta^{82 / 78} \mathrm{Se}=+0.41 \pm 0.33 \%, \mathrm{n}=15\right)$.

339 - Volcanogenic massive sulfides (VMS) from the late Archean Kidd Creek Basin (2.7 Gyr;

$\left.340 \delta^{82 / 78} \mathrm{Se}=+0.28 \pm 0.24 \%, \mathrm{n}=5\right)$ are statistically indistinguishable from associated marine black

341 shales $\left(\delta^{82 / 78} \mathrm{Se}=+0.07 \pm 0.22 \%, \mathrm{n}=5\right)\left(\mathrm{p}_{\text {one-tailed }}=0.10\right)$, but show a markedly smaller range

342 and a large isotopic enrichment compared to modern hydrothermal sulfides from the Mid- 
343 Atlantic Ridge $\left(\delta^{82 / 78} \mathrm{Se}=-0.98 \pm 0.81 \%, \mathrm{n}=51\right.$, Rouxel et al., 2004 $)$ and late Devonian VMS

344 deposits from northwestern Canada $\left(\delta^{82 / 78} \mathrm{Se}=-1.88 \pm 2.33 \%, \mathrm{n}=23\right.$, Layton-Matthews et al., 345 2013).

346 - In the Mesoproterozoic Belt Supergroup (1.47 Gyr, Fig. 4c), isotopically light values $\left(\delta^{82 / 78} \mathrm{Se}\right.$

$347=-0.07 \pm 0.43 \%, \mathrm{n}=7$ ) mainly occur in offshore facies to the west, whereas onshore facies from 348 the eastern basin margin tend to be relatively heavy $\left(\delta^{82 / 78} \mathrm{Se}=+0.73 \pm 0.33 \%, \mathrm{n}=8\right)$. Here, the 349 offshore sites are located closer to the opening of the basin towards the ocean but also closer to 350 the proposed major riverine inflow from the unsampled western basin margin (Ross and 351 Villeneuce, 2003). Deep basinal facies from the roughly coeval Roper Basin (1.36 Gyr; $\delta^{82 / 78} \mathrm{Se}$ $352=+0.53 \pm 0.20 \%, \mathrm{n}=7)$ and samples of intermediate water depth from the Taoudeni Basin (1.1 $353 \mathrm{Gyr} ; \delta^{82 / 78} \mathrm{Se}=+0.45 \pm 0.52 \%$ o, $\mathrm{n}=5$ ) are generally positive. If these sediments were deposited 354 distal to the most significant riverine water inflow, then all three Mesoproterozoic basins may 355 show relative isotopic enrichment with increasing distance from the major Se source.

356 - Our results for coastal Atlantic samples from the Cretaceous (120 Myr) Ocean Anoxic Event I 357 (OAE I) are all negative $\left(\delta^{82 / 78} \mathrm{Se}=-0.41 \pm 0.23 \%, \mathrm{n}=8\right.$, Fig. $\left.4 \mathrm{f}\right)$, whereas Mitchell et al. $(2012)$ 358 found primarily positive values $\left(\delta^{82 / 78} \mathrm{Se}=+0.19 \pm 0.25 \%, \mathrm{n}=27\right)$ in deep-marine Atlantic 359 samples from OAE II (93 Myr). Hence, taken together, the Atlantic Ocean may have displayed a 360 basinal gradient during anoxic stages.

361 When all normal marine data points are combined, $\delta^{82 / 78}$ Se is not correlated with $\delta^{34} \mathrm{~S}\left(\mathrm{r}^{2}\right.$ $362=0.005)$, TS $\left(r^{2}=0.05\right)$, TOC $\left(r^{2}=10^{-5}\right)$ or TSe $\left(r^{2}=0.02\right)$ and only weakly with $\delta^{13} \mathrm{C}_{\mathrm{org}}\left(\mathrm{r}^{2}=\right.$ 363 0.22). TSe shows moderate correlations with TS and TOC in logarithmic space $\left(\mathrm{r}^{2}=0.31\right.$ and 3640.50 , respectively, Fig. 5), but much less so in linear space $\left(r^{2}=0.01\right.$ and 0.22$)$. We hypothesize 365 that the logarithmic correlation is partly a result of lithology and sedimentation rate, i.e. fine- 
366 grained black shales with low sedimentation rates tend to accumulate a larger quantity of reduced

$367 \mathrm{Se}\left(\mathrm{Se}^{-\mathrm{II}}\right.$ or $\left.\mathrm{Se}^{0}\right)$, sulfide $\mathrm{S}$ and organic $\mathrm{C}$ than siltstones or more rapidly accumulating sediments,

368 regardless of whether the three elements are biogeochemically related. Based on the relatively

369 weak correlations in linear space, we therefore conclude that Se does not strictly follow either S

370 or organic matter under all conditions. However, we do see moderately strong correlations

371 between $\delta^{82 / 78} \mathrm{Se}$ and TOC in a few individual basins, in particular the Ghaap Group $\left(\mathrm{r}^{2}=0.64, \mathrm{n}\right.$

$372=15$, Fig. 4e) and the Belt Supergroup $\left(r^{2}=0.41, n=15\right.$, Fig. $\left.4 d\right)$. In both cases, $\delta^{82 / 78}$ Se values

373 decrease with increasing TOC, but TSe is not correlated with TOC or TS. TOC data are not

374 available for the marine Fortescue Group. None of the other basins for which we have more than

37510 data points show strong correlations.

376

377 4. Discussion

After first assessing the quality of samples analyzed in this study, we describe a

379 conceptual model of the modern Se cycle based on our compilation of literature data. We then

380 use this as a platform to reconstruct the evolution of the global Se cycle through time.

\section{4.1. Sample quality}

Diagenesis, metamorphism or weathering can potentially alter primary geochemical

384 features in rock samples. As discussed in Section 4.2, diagenetic Se oxyanion reduction may

385 occur in sediments deposited under oxic conditions where the Se supply is relatively high.

386 Evidence for diagenetic oxyanion reduction in ancient rocks may thus be a diagnostic feature of

387 oxygenated conditions and is therefore not an impediment to this study. Other diagenetic 
reactions between reduced Se phases, such as exchange of $\mathrm{Se}^{-\mathrm{II}}$ between organic matter and

389 pyrite, should not lead to isotopic fractionations, especially within bulk rocks.

391 essentially immobile during metamorphic alteration, therefore isotopic alteration of this phase

392 should be trivial. Organic $\mathrm{Se}^{-\mathrm{II}}, \mathrm{Se}^{0}$ or adsorbed $\mathrm{Se}^{\mathrm{IV}}$ may be more sensitive to metamorphism,

393 but associated isotopic fractionations are unknown. Most of our samples are of sub-greenschist

394 metamorphic grade; only the Witwatersrand samples are greenschist grade. In the S isotope

395 literature, metamorphic effects are commonly ignored in these metamorphic facies, and given the

396 higher mass of Se relative to $\mathrm{S}$, it is unlikely that Se is more mobile than $\mathrm{S}$ under metamorphic

397 conditions. We therefore believe that our results are not significantly affected by metamorphism.

398 Weathering has been shown to cause large Se isotopic fractionations of several permil in

399 a recent study of unusually Se-rich soils (5-26,000 ppm) from China (Zhu et al., 2014), where Se

400 was apparently oxidized and then partially re-reduced during aqueous transport. However, in Se-

401 poor soils $(0.1-0.5 \mathrm{ppm})$ from Germany the range of fractionation was much smaller $(<0.5 \%$,

402 Schilling et al., 2011b), suggesting that the large fractionations observed by Zhu et al. (2014)

403 may not necessarily be representative of typical weathering environments. Measurable isotopic

404 effects may be restricted to Se-rich settings where the Se weathering flux is unusually high, such

405 that partial reduction can add significantly to surrounding rocks. Se oxidation by itself does not

406 impart a detectable isotopic fractionation (Johnson et al., 1999). Because most of our samples are

407 from drill cores while any outcrop samples were relatively fresh and had their outer surfaces

408 removed with a rock saw, weathering probably did not have significant effects on our results.

\section{4.2. Proposed modern Se cycle}


The relatively low $\delta^{82 / 78} \mathrm{Se}$ values preserved in sediments deposited in or near open oxic

412 conditions $\left(\delta^{82 / 78} \mathrm{Se}_{\mathrm{avg}}=-0.10 \pm 0.21 \%\right.$, range $-0.90 \%$ o to $+0.41 \%$ ) compared to the presumed

413 composition of dissolved Se oxyanions in seawater $\left(\delta^{82 / 78} \mathrm{Se} \geq+0.3\right.$, Section 3.1$)$ are likely the

414 result of non-quantitative $\mathrm{Se}^{\mathrm{VI}}$ or $\mathrm{Se}^{\mathrm{IV}}$ reduction to $\mathrm{Se}^{0}$ or inorganic $\mathrm{Se}^{-\mathrm{II}}$ under suboxic

415 conditions during diagenesis or in locally suboxic bottom water (Fig. 6) (Shore, 2010). The

416 mechanism may have been either biological dissimilatory reduction or abiotic reduction. We

417 emphasize that our 'open oxic ocean' category includes data from an oxygen minimum zone in

418 the Arabian Sea (Mitchell et al., 2012) and therefore does not exclusively represent oxic

419 conditions; however, all data points are from environments that are part of the open ocean and

420 connected to the oxic water column, i.e. they are characterized by a high Se oxyanion supply,

421 unlike restricted anoxic basins. Non-quantitative Se oxyanion reduction during diagenesis under

422 an oxic water column or in locally suboxic bottom water may thus explain why residual $\mathrm{Se}^{\mathrm{VI}}$ and

$423 \mathrm{Se}^{\mathrm{IV}}$ dissolved in modern oxic seawater are relatively enriched compared to average crust $(\sim 0 \%$,

424 Rouxel et al., 2002). Addition of small amounts of isotopically heavy adsorbed $\mathrm{Se}^{\mathrm{IV}}(\sim+0.3 \%$,

425 Rouxel et al., 2002) or organic $\mathrm{Se}^{-\mathrm{II}}\left(\sim+0.3 \%\right.$, Mitchell et al., 2012) to isotopically light $\mathrm{Se}^{0}$ and

426 inorganic $\mathrm{Se}^{-\mathrm{II}}$ may explain why bulk $\delta^{82 / 78} \mathrm{Se}$ values in open marine sediments are not as

427 negative as one might expect given the fairly large fractionations associated with reduction

428 reactions observed in laboratory simulations (Johnson et al., 1999). Sequential extraction

429 experiments indeed show that sediments and soils commonly contain multiple Se phases with

430 distinct isotopic compositions (Kulp and Pratt, 2004; Schilling et al., 2014b). Sequential

431 extractions have so far not been carried out on open marine sediments deposited under an oxic

432 water column, but we would predict a mixture of isotopically light inorganic $\mathrm{Se}^{-\mathrm{II}}$ and/or $\mathrm{Se}^{0}$ and 433 small amounts of isotopically heavy $\mathrm{Se}^{\mathrm{IV}}$ and/or organic $\mathrm{Se}^{-\mathrm{II}}$. 
In the $\mathrm{C}$ and $\mathrm{S}$ cycle, the isotopically heavy reservoirs complementary to isotopically

435 light reduced phases (organic matter and sulfide, respectively) are carbonate and sulfate minerals.

436 In the case of $\mathrm{Se}$, however, the most oxidized species $\mathrm{Se}^{\mathrm{VI}}$ does not form major mineral deposits

437 and incorporation into carbonate or sulfate minerals is probably minor $(<0.025 \mathrm{ppm}$ total Se,

438 Hagiwara, 2000). Adsorbed $\mathrm{Se}^{\mathrm{IV}}$ on FeMn-oxides may be the most significant isotopically heavy

439 reservoir today, complementary to the relatively light siliciclastic sediments from the open

440 ocean; more data are needed to test this possibility. Based on our data compilation, we propose

441 that sediments from restricted anoxic basins, which tend to be isotopically slightly heavier than

442 sediments of open oxic basins, may represent another significant complementary positive

443 repository to the isotopically lighter sediments from the global oxic ocean (Fig. 6). Under anoxic

444 conditions, Se assimilated into biomass is not recycled by oxidation, leading to low

445 concentrations of Se oxyanions in the anoxic water column (Cutter, 1982; Shore, 2010; Mitchell

446 et al., 2012). Therefore, Se oxyanion reduction is likely more quantitative than under diagenetic

447 conditions beneath an oxic water column where the concentrations of Se oxyanions are high.

448 Following Rayleigh distillation, net isotopic fractionations during reduction relative to the crustal

449 source may thus be smaller. Furthermore, compared to open oxic settings, organic Se may be

450 more abundant. Biomass may also be isotopically heavier than in the open ocean, because with

451 more quantitative oxyanion reduction, residual $\mathrm{Se}^{\mathrm{IV} / \mathrm{VI}}$, i.e. the substrate for assimilation into

452 biomass, may be heavier than $+0.3 \%$. So although restricted anoxic settings do not appear to

453 fully capture the isotopic composition of marine $\mathrm{Se}^{\mathrm{IV} / \mathrm{VI}}$ (as is the case with Mo, Anbar, 2004),

454 they at least approach it and are distinct from open marine oxic settings where the supply of Se

455 oxyanions is higher. This means that the marine Se cycle should have evolved markedly through 
456 time as the global ocean evolved from an anoxic to an oxic state and the residence time of Se

457 oxyanions presumably increased.

\subsection{Mid-Archean}

Throughout the Archean, the global ocean was generally anoxic (Poulton and Canfield,

461 2011; Lyons et al., 2014a), but oxygenic photosynthesis may have created local oxygen oases

462 since at least 3.0 Gyr (Crowe et al., 2013; Planavsky et al., 2014a). Moreover, relatively high

463 levels of TOC in the absence of Fe or S mineralization in the 3.2 Gyr Soanesville Group have

464 been interpreted as potential indirect evidence of even older cyanobacterial oxygenic

465 photosynthetic activity (Buick, 2008). However, the low concentrations of Se in mid-Archean

466 sediments from the Soanesville Group and the Witwatersrand Supergroup suggest that there was

467 no significant Se flux into the ocean. It is important to note that, unlike Mo for example, Se does

468 not require $\mathrm{H}_{2} \mathrm{~S}$ in the water column or in pore waters to become enriched in anoxic sediments,

469 because it can be immobilized by reduction to solid $\mathrm{Se}^{0}$. Hence the absence of $\mathrm{H}_{2} \mathrm{~S}$ alone cannot

470 explain low TSe concentrations in mid-Archean sediments. Instead it is more likely that

471 atmospheric $\mathrm{pO}_{2}$ was too low for a significant oxidative weathering flux of Se into the ocean

472 (Reinhard et al., 2013a); any $\mathrm{O}_{2}$ that was biologically produced at this time (Crowe et al., 2013;

473 Planavsky et al., 2014a) was probably rapidly consumed by reductants with lower redox

474 potentials. Mid-Archean marine sediments have TSe concentrations $(0.20 \pm 0.13$ ppm, removing

475 one outlier of 2.2 ppm from the Parktown Formation) only slightly above that of the upper crust

476 (0.09 ppm, Rudnick and Gao, 2014), but they are isotopically heavier by $0.65 \pm 0.58 \%$. Given

477 that fluvial sediments from the Witwatersrand Supergroup are slightly lighter $(+0.30 \pm 0.19 \%$,

478 Fig. 4a), it is possible that there was a small but non-trivial flux of $\mathrm{Se}^{\mathrm{IV} / \mathrm{VI}}$ from $\mathrm{O}_{2}$ oases on land 
479 into the anoxic ocean, and partial reduction or adsorption occurred during fluvial transport,

480 rendering residual dissolved $\mathrm{Se}^{\mathrm{IV} / \mathrm{VI}}$ isotopically enriched. $\mathrm{S}$ isotope data from the Witwatersrand

481 Basin are also consistent with a small oxidative weathering source, because they point towards a

482 crustal non-atmospheric sulfate contribution (Guy et al., 2012; Guy et al., 2014). However, we

483 cannot rule out that the Se was instead of hydrothermal or volcanic origin and that isotopic

484 fractionation occurred in the deep ocean or in volcanic eruptions.

\subsection{Late Archean}

The marked increase in average TSe concentrations in samples of the late Archean Fortescue Group and the Ghaap Group and in the Kidd Creek shales (Fig. 3b), concurrent with 489 an increase in TS concentrations (Stïeken et al., 2012) (note relatively small change in TSe/TS, 490 Fig. 3c), can be due to either unusually high volcanic or hydrothermal activity or the onset of 491 oxidative Se weathering on land. A hydrothermal Se source can probably be ruled out because 492 we also find relatively high Se concentrations in the lacustrine Tumbiana Fm (Table A1), which 493 shows no evidence of hydrothermal activity (Buick, 1992). Moreover, the modern hydrothermal 494 flux of Se into the ocean $\left(\sim 5 \cdot 10^{5} \mathrm{~mol} / \mathrm{yr}\right.$, Rubin, 1997) is so low compared to other sources (see 495 below) that it would have had to increase unrealistically.

496 While enhanced hydrothermal input in the late Archean cannot explain the TSe increase, 497 we are unable to distinguish unambiguously between increasing volcanism and oxidative 498 weathering as Se sources at that time. Today, volcanic eruptions generate $\sim 1 \cdot 10^{7} \mathrm{~mol} / \mathrm{yr}$ of Se, 499 including gaseous and particulate $\mathrm{Se}^{0}, \mathrm{SeO}_{2}$ and $\mathrm{H}_{2} \mathrm{Se}$ (Suzuoki, 1965; Mosher and Duce, 1987; 500 Wen and Carignan, 2007). On the modern Earth, this volcanic flux is much smaller than the 501 riverine Se flux to the ocean $\left(\sim 6 \cdot 10^{7} \mathrm{~mol} / \mathrm{yr}\right)$. The latter was calculated assuming a river flux of 
$5023.7 \cdot 10^{16} 1 / \mathrm{yr}$ (Henderson and Henderson, 2009) with an average Se oxyanion load of $1.5 \mathrm{nM}$

503 (Conde and Alaejos, 1997). However, this number includes uncertain anthropogenic

504 contributions, whereas organic and particulate Se are not accounted for. It is thus probable that

505 enhanced volcanism in the Precambrian dominated over the weathering flux as long as oxidative

506 weathering was muted. Isotopic Se fractionations associated with volcanic processes are

507 unknown, and so we cannot rule out that unprecedented volcanic activity caused both the rise in

508 TSe $\sim 2.7 \mathrm{Gyr}$ and the significant isotopic contrast between non-marine and marine sediments in

509 the Fortescue Group (Fig. 4b). For example, one could envision a scenario where volcanogenic

$510 \mathrm{SeO}_{2}$ dissolved in rivers proximal to the volcanic source, forming $\mathrm{SeO}_{3}{ }^{2-}$ oxyanions, which were

511 then isotopically fractionated by partial reduction during transport to the ocean. This would have

512 produced isotopically depleted Se phases in fluvio-lacustrine sediments, as observed. The

513 residual isotopically enriched Se would have been carried to the ocean and deposited in marine

514 sediments following quantitative reduction or assimilation into marine biomass.

515 However, several lines of evidence support the alternative conclusion that Se oxyanions

516 in river water were sourced from the onset of oxidative weathering rather than volcanism in the

517 late Archean. First, the volcanic flux should also have been high in the mid-Archean and there is

518 no independent evidence for a large increase in volcanic activity throughout the late Archean.

519 Second, if volcanic eruptions were massive enough to increase marine Se concentrations by

520 almost an order of magnitude, then large amounts of $\mathrm{SeO}_{2}$ should have rained out directly into

521 the ocean, so one would expect to see more negative fractionations in marine sediments. Hence

522 the isotopic gradient from non-marine to marine facies is more readily explained if Se oxyanions

523 were sourced locally in oxygen oases on land (e.g. Buick, 1992; Flannery and Walter, 2012;

524 Lalonde and Konhauser, 2015). Third, Se concentrations peak during the 'whiff of oxygen' at 2.5 
525 Gyr (Anbar et al., 2007; Stüeken et al., 2015), concurrently with Mo and Re, which cannot be

526 explained by volcanism. Molybdenum concentrations and isotopic fractionations (Siebert et al.,

527 2006; Wille et al., 2007; Kendall et al., 2010) as well as other geochemical proxies including

528 sulfur (Stüeken et al., 2012), nitrogen (Garvin et al., 2009; Godfrey and Falkowski, 2009) and

529 organic carbon isotopes (Eigenbrode and Freeman, 2006) all support mildly or locally oxidative

530 conditions in surface environments since $\sim 2.7$ Gyr, making it plausible that also some Se was

531 oxidized on land at that time.

532 Recent evidence suggests that oxidation of $\mathrm{Cr}^{\mathrm{III}}$ to $\mathrm{Cr}^{\mathrm{VI}}$ may have been subdued until the

533 Neoproterozoic (Frei et al., 2009; Planavsky et al., 2014b), which may have also precluded

534 abundant production of $\mathrm{Se}^{\mathrm{VI}}$ in the earlier Precambrian because $\mathrm{Se}^{\mathrm{VI}}$ and $\mathrm{Cr}^{\mathrm{VI}}$ have similar redox

535 potentials (Brookins, 1988). However, $\mathrm{Se}^{\mathrm{IV}}$ has a much lower redox potential than $\mathrm{Cr}^{\mathrm{VI}}$ and $\mathrm{Se}^{\mathrm{VI}}$

536 (Brookins, 1988) and could thus have been a stable ion in lakes and rivers and the surface ocean

537 long before the Neoproterozoic.

538 New data from the early Cambrian (Wen et al., 2014) show large Se isotopic

539 fractionations under ferruginous conditions, indicative of partial oxyanion reduction in the open

540 ocean, which suggests that although $\mathrm{Fe}^{\mathrm{II}}$ is capable of reducing $\mathrm{Se}^{\mathrm{IV}}$ (Zingaro et al., 1997), the

541 reaction is evidently too slow to cause complete reduction. Thus $\mathrm{Se}^{\mathrm{IV}}$ could have been produced

542 in late Archean oxygen oases proximal to $\mathrm{O}_{2}$-producing microbial mats (e.g. Buick, 1992;

543 Flannery and Walter, 2012; Lalonde and Konhauser, 2015), and carried to the ocean in anoxic

544 Fe ${ }^{\mathrm{II}}$-dominated (Rasmussen and Buick, 1999) river systems.

545 Regardless of the whether $\mathrm{Se}^{\mathrm{IV}}$ was sourced from volcanic $\mathrm{SeO}_{2}$ or oxidative weathering,

546 and assuming that Se isotopic fractionations associated with volcanic gas phase reactions are

547 insignificant, the wide range in $\delta^{82 / 78}$ Se values in the late Archean suggests that Se oxyanion 
548 reduction occurred at this time, because fractionations associated with adsorption or assimilation

549 of Se (<0.7 \%o, Johnson et al., 1999; Clark and Johnson, 2010; Mitchell et al., 2013) are too

550 small to explain the data. Both processes may, however, contribute to the observed scatter.

\section{4.5. Paleo- and Mesoproterozoic}

Se isotopes and concentrations in marine mudrocks do not change markedly from the late

554 Archean to the Paleo- and Mesoproterozoic. We found temporary $\delta^{82 / 78}$ Se enrichments up to

$555+2.01 \%$ in the 2.32 Gyr Pretoria Group immediately after one of the Paleoproterozoic glaciation

556 events, which may be a result of the proposed Lomagundi atmospheric $\mathrm{O}_{2}$ overshoot between

557 2.35 and 2.05 Gyr (Bekker et al., 2004; Bekker and Holland, 2012; Planavsky et al., 2012;

558 Hardisty et al., 2014; Scott et al., 2014). Intuitively, more oxidizing conditions should lead to

559 more negative values, as in the modern ocean (Section 4.2). However, it is conceivable that

560 throughout the Precambrian a large fraction of Se dissolved in rivers was organically complexed,

561 more so than today (Doblin et al., 2006), due to interaction with microbial life on land. In that

562 case, moderately high atmospheric $\mathrm{pO}_{2}$ during the $\mathrm{O}_{2}$ overshoot could have increased the

563 proportion of Se oxyanions in rivers relative to organically complexed Se. Consequently, a larger

564 fraction of fluvial Se could have been subject to reduction, such that the residue would have been

565 pushed to higher positive $\delta^{82 / 78}$ Se values. Alternatively, positive values could be explained by the

566 opposite effect, i.e. a smaller amount of Se oxyanions in rivers subject to a relatively larger

567 degree of partial reduction and hence more positive values in the residual dissolved fraction that

568 reached the ocean. However, in that case, large positive values up to $2 \%$ should be relatively

569 common in the Precambrian and concentrations in marine sediments should drop, contrasting

570 with the observed high concentrations in the Pretoria Group. Hence the Se oxyanion flux into the 
571 ocean was probably higher in the Paleoproterozoic than in the late Archean. The high $\delta^{82 / 78} \mathrm{Se}$

572 values at 2.32 Gyr may thus be an enhanced version of those recorded during the 'whiff of

573 oxygen' around 2.5 Gyr (Anbar et al., 2007; Stüeken et al., 2015).

574 Cr isotope data suggest that in the Paleo- and Mesoproterozoic the atmosphere was still 575 not oxidizing enough for the production of abundant $\mathrm{Cr}^{\mathrm{VI}}$ (Frei et al., 2009; Planavsky et al., $5762014 b$ ). If so, then Se oxyanions in rivers were probably still dominated by Se ${ }^{\mathrm{IV}}$. However, initial 577 reports of Se isotopes in $\mathrm{Se}^{\mathrm{IV}}$ adsorbed to BIF of Paleoproterozoic age show very negative values 578 (Schilling et al., 2014a), consistent with non-quantitative reduction of $\mathrm{Se}^{\mathrm{VI}}$ to $\mathrm{Se}^{\mathrm{IV}}$ in seawater on 579 the outer shelf and suggesting that the surface ocean was perhaps locally more oxic than non580 marine environments, such that $\mathrm{Se}^{\mathrm{VI}}$ was stable. But this situation still contrasts with the modern 581 ocean where marine $\mathrm{Se}^{\mathrm{IV}}$ is derived from organic-Se $\mathrm{e}^{-\mathrm{II}}$ oxidation rather than $\mathrm{Se}^{\mathrm{VI}}$ reduction 582 (Cutter and Bruland, 1984). Hence the BIF data may be further evidence for a strong chemocline 583 within the Paleoproterozoic water column. Isotopically light $\mathrm{Se}^{\mathrm{IV}}$ probably adsorbed to Fe-oxide 584 particles in the photic zone and subsequently settled on the seafloor. Kerogenous shales, as 585 analyzed in this study, could have preserved the composition of the residual heavy Se ${ }^{\mathrm{VI}}$ by 586 quantitative reduction below the chemocline.

588 Creek Inlier, the Roper Basin, the Belt Basin and the Taoudeni Basin do not show any 589 enrichments above $+1.1 \%$ (Fig. 3a) and are generally similar to the late Archean. However, data 590 along a basinal profile in the Belt Basin, where we found more negative $\delta^{82 / 78}$ Se closer to the 591 major river inflow and positive values along the restricted basin margin (Fig. 4c), suggest that 592 most $\mathrm{Se}^{\mathrm{IV} / \mathrm{VI}}$ reduction may have occurred in the ocean rather than in rivers. As surface 593 environments became more oxidizing from the late Archean to the Proterozoic (Lyons et al., 
594 2014a), partial $\mathrm{Se}^{\mathrm{IV} / \mathrm{VI}}$ reduction may thus have moved further towards the ocean. While

595 oxidative weathering in the late Archean (if it occurred) was perhaps restricted to oxygen oases

596 (Lalonde and Konhauser, 2015), it may have been more widespread in the Proterozoic, even if

597 the redox potential at those weathering sites did not increase markedly (Planavsky et al., 2014b).

598 However, Se oxyanions were probably not as well-mixed throughout the water column as they

599 are today and were perhaps more rapidly consumed on a regional scale. As in the Archean, the

600 total range of $\delta^{82 / 78}$ Se values in the Proterozoic is too large to be explained by adsorption or

601 assimilation alone, but these processes may contribute to the observed scatter in the data.

602

\section{4.6. Phanerozoic}

604 For large parts of the Phanerozoic, the marine Se cycle was probably similar to that of 605 today (Section 4.2), as indicated by the more frequent occurrence of negative $\delta^{82 / 78}$ Se values in 606 marine sediments from various localities and an average difference of $-0.64 \%$ compared to 607 Proterozoic. We note that also Phanerozoic hydrothermal deposits (Rouxel et al., 2004; Layton608 Matthews et al., 2013) are isotopically lighter than Archean counterparts from the Kidd Creek by 609 more than 1\%, suggesting that the supply of Se oxyanions from oxic seawater to hydrothermal 610 systems increased. Hence Se oxyanions were probably more abundant throughout the water 611 column, except in restricted anoxic basins. The drop in TS/TSe ratios by a factor of 4.6 (Fig. 3c) 612 in open marine sediments suggests an increase in the total Se flux into the ocean, possibly as a 613 result of increasing redox potential at weathering sites (Planavsky et al., 2014b) leading to the 614 production of $\mathrm{Se}^{\mathrm{VI}}$ rather than $\mathrm{Se}^{\mathrm{IV}}$ as in the earlier Precambrian (Sections 4.4, 4.5). Oxygenation 615 of the deep ocean in the Neoproterozoic (Canfield et al., 2007; Johnston et al., 2012; Sahoo et al., 616 2012) would further have initiated seafloor weathering as an additional Se oxyanion source. 
617 During anoxic events, such as in the Cretaceous, the Se cycle probably reverted to its

618 Precambrian state, as shown by the gradient between negative $\delta^{82 / 78}$ Se values from coastal

619 samples during OAE-I and positive $\delta^{82 / 78}$ Se values from deep marine samples during OAE-II

620 (Mitchell et al., 2012), assuming Se sources were comparable during these events.

$621 \quad$ Large et al. (2014) recently reported a significant increase of Se concentration in

622 sedimentary pyrite crystals across the Precambrian-Cambrian boundary, which is not as strongly

623 reflected in our data from bulk sediments. It is conceivable that the difference between the two

624 datasets is evidence for a change in Se speciation rather than total supply. In the Precambrian,

625 most sedimentary Se was probably organic-bound, whereas in the Phanerozoic the greater

626 abundance of Se oxyanions in an oxic water column may have allowed for more dissimilatory

627 reduction and incorporation of inorganic $\mathrm{Se}^{-\mathrm{II}}$ into sulfide minerals. If so, then the contrast

628 between our whole-rock abundance data and that of the pyrite isolates presented by Large et al.

629 (2014) is perhaps further evidence for widespread ocean oxygenation in the Neoproterozoic.

\section{Conclusions}

Our data support several conclusions about the evolution of the Earth's redox state and

633 the global biogeochemical Se cycle:

634 1. Concurrently rising Archean TS and TSe between 2.8 Gyr and 2.7 Gyr and the significant isotopic contrast between marine and non-marine samples in the late Archean are consistent with an early onset of oxidative Se weathering in locally oxygenated terrestrial habitats long before the global rise of atmospheric $\mathrm{pO}_{2}$ levels during the Paleoproterozoic GOE. However, we cannot disprove the possibility that both features were caused by volcanic Se production as long as isotopic fractionations and Se abundances associated 
with volcanic eruptions are poorly known. In either case, $\mathrm{Se}^{\mathrm{IV}}$ was probably more abundant than $\mathrm{Se}^{\mathrm{VI}}$, given the inferred low abundance of $\mathrm{Cr}^{\mathrm{VI}}$ (Frei et al., 2009; Planavsky et al., 2014b), which has a similar redox potential as $\mathrm{Se}^{\mathrm{VI}}$ (Brookins, 1988). Se oxyanions produced during weathering were partially reduced during fluvial transport to the ocean.

2. The GOE itself ( 2.4-2.3 Gyr) (Bekker et al., 2004) did not leave a marked imprint on the Se isotopic or abundance record, except for perhaps a small enrichment in $\delta^{82 / 78}$ Se during the proposed $\mathrm{O}_{2}$ overshoot between 2.35 Gyr and 2.05 Gyr (Bekker and Holland, 2012; Planavsky et al., 2012; Hardisty et al., 2014; Scott et al., 2014). This may be because organic complexation of Se during fluvial transport and in the ocean likely reduced the maximum observed fractionation in sediments.

3. A relatively greater abundance of Se oxyanions may have reached the ocean in the Proterozoic compared to the Archean, but reduction probably occurred along the chemocline, perhaps in the vicinity of river deltas. However, our lack of data from truly open marine settings, i.e. outside of epicontinental basins, makes it impossible to assess how Se behaved in the oligotrophic ocean. If significant portions of the deep ocean were oxic (Reinhard et al., 2013b; Ader et al., 2014), then partial Se ${ }^{\mathrm{IV} / \mathrm{VI}}$ reduction and isotopic fractionation could also have occurred offshore, similar to today.

4. The most notable transition in the Se isotopic record occurred at some time between the Mesoproterozoic and the mid-Paleozoic, when $\delta^{82 / 78}$ Se values shifted from dominantly positive to frequently negative. The transition between the Proterozoic and modern Se cycle probably occurred during the oxygenation of the deep ocean in the Neoproterozoic (Canfield et al., 2007; Johnston et al., 2012; Sahoo et al., 2012). While $\mathrm{Se}^{\mathrm{IV}}$ was perhaps 
the dominant Se oxyanion in the earlier Precambrian, increasing atmospheric oxygen levels in the Neoproterozoic (Planavsky et al., 2014b) may have stabilized $\mathrm{Se}^{\mathrm{VI}}$.

5. In the modern ocean, sediments from localities that are well-connected to the open oxic ocean are on average isotopically depleted relative to the crustal source and dissolved and/or too short-lived prior to the evolution of complex eukaryotic life.

677 accepted view of Earth's redox evolution (Lyons et al., 2014b), but they have somewhat limited

678 utility as a paleoredox proxy for two main reasons. First, whole rock analyses are likely to 679 represent mixtures of heterogeneous Se phases, and in many siliciclastic samples, organic $\mathrm{Se}^{-\mathrm{II}}$ is 680 probably always one of the major phases. If organic $\mathrm{Se}^{-\mathrm{II}}$ captures the composition of seawater 681 (Section 4.2), then it will mask any negative fractionations carried by inorganic $\mathrm{Se}^{-\mathrm{II}}$ or $\mathrm{Se}^{0}$.

682 Measured isotopic fractionations in whole-rocks are therefore relatively muted, in some cases

683 making it more difficult to unambiguously distinguish between oxyanion reduction and 684 adsorption or assimilation as the major fractionating mechanism. Second, Se isotopes appear to 685 have been fractionated during transport to the ocean or along ocean margins for most of Earth's 
686 history, except perhaps in the Phanerozoic when the total average of marine $\delta^{82 / 78}$ Se values is

687 close to average crust, indicating quantitative transfer between reservoirs. Without spatial

688 resolution it will thus be impossible to know the composition of Se entering a specific ocean

689 basin. Hence, results from a single site cannot readily be extrapolated to the global ocean.

690 However, detailed stratigraphic studies or large datasets, such as the one presented in this paper,

691 have the potential to reveal trends. Indeed, the most notable trend in our Se isotopic data lends

692 further support to the idea of deep ocean oxygenation in the Neoproterozoic.

693

694 Acknowledgments

695 All authors except DC contributed samples and background information, DC had the idea

696 of looking for MIF-Se, EES prepared the samples, performed the analyses, interpreted the data

697 and wrote the manuscript with advice and contributions from RB. The project was financially

698 supported by a University of Washington Royalty Research grant to RB, the National Science

699 Foundation grant EAR0921580 to RB, NASA Exobiology Program Grant NNX10AQ90G to DC,

700 and the NAI Virtual Planetary Laboratory at the University of Washington. We thank the UW

701 Isotope Geochemistry Lab and the UW Isolab for technical support. A. Knoll, B. Wing and N.

702 Planavsky are thanked for additional samples. 
703 Table 1: Major stratigraphic units analyzed in this study. Uncertainties are reported as $1 \sigma$.

\begin{tabular}{|c|c|c|c|c|c|c|c|}
\hline Unit & Location & $\begin{array}{c}\text { Age } \\
\text { [Gyr] }\end{array}$ & Setting & $\mathbf{n}$ & $\begin{array}{c}\delta^{82 / 78} \mathrm{Se} \\
{[\% 0]}\end{array}$ & $\begin{array}{c}\text { log(TSe) } \\
\text { [ppm] }\end{array}$ & $\begin{array}{l}\log (\mathrm{S} / \mathrm{Se}) \\
{[\% / p p m]}\end{array}$ \\
\hline Soanesville Gp. & Australia & 3.19 & upper slope, open marine & 9 & $+0.64 \pm 0.18$ & $-0.89 \pm 0.10$ & $-0.55 \pm 0.14$ \\
\hline \multirow{3}{*}{ Witwatersrand Spgp. } & \multirow{3}{*}{ S. Africa } & $2.94-2.92$ & fluvial & 5 & $+0.30 \pm 0.19$ & $-0.59 \pm 0.22$ & $+0.10 \pm 0.37$ \\
\hline & & $2.96-2.87$ & proximal marine, possibly restricted epeiric sea & 8 & $+0.74 \pm 0.28$ & $-0.66 \pm 0.26$ & $-0.22 \pm 0.45$ \\
\hline & & $2.96-2.94$ & distal marine, epeiric sea, open to the ocean & 5 & $+0.63 \pm 0.51$ & $-0.46 \pm 0.49$ & $-0.34 \pm 0.45$ \\
\hline Pongola Spgp. & S. Africa & 2.90 & epeiric sea connected to the ocean, possibly restricted & 2 & $+0.41 \pm 0.44$ & $-0.76 \pm 0.09$ & $+0.05 \pm 0.04$ \\
\hline \multirow{2}{*}{ Kidd Creek deposit } & \multirow{2}{*}{ Canada } & \multirow{2}{*}{2.71} & open marine shelf & 5 & $+0.07 \pm 0.22$ & $+0.55 \pm 0.35$ & \\
\hline & & & volcanogenic massive sulfide deposit (VMS) & 5 & $+0.28 \pm 0.24$ & $+2.73 \pm 0.78$ & \\
\hline \multirow{3}{*}{ Fortescue Gp. } & \multirow{3}{*}{ Australia } & $2.78-2.72$ & fluvio-lacustrine & 19 & $-0.28 \pm 0.67$ & $+0.07 \pm 0.58$ & $-0.78 \pm 0.67$ \\
\hline & & 2.65 & open marine shelf, onshore & 7 & $+0.32 \pm 0.12$ & $-0.23 \pm 0.21$ & \\
\hline & & 2.65 & open marine shelf, offshore & 21 & $+0.38 \pm 0.30$ & $-0.02 \pm 0.40$ & $+0.27 \pm 0.14$ \\
\hline Ghaap Gp. & S. Africa & $2.56-2.52$ & open marine shelf & 15 & $+0.41 \pm 0.33$ & $+0.23 \pm 0.51$ & $-0.08 \pm 0.63$ \\
\hline Hamersley Gp. & Australia & 2.49 & open marine shelf & 3 & $+0.46 \pm 0.66$ & $+0.16 \pm 0.47$ & \\
\hline Pretoria Gp. & S. Africa & 2.32 & epeiric sea, open to the ocean & 8 & $+1.13 \pm 0.56$ & $+0.43 \pm 0.78$ & $-0.33 \pm 0.51$ \\
\hline Namoona Gp. & Australia & 1.9 & intracontinental rift basin, possibly restricted & 8 & $-0.07 \pm 0.13$ & $+0.47 \pm 0.68$ & $-0.07 \pm 0.13$ \\
\hline Animikie Gp. & Canada & $1.87-1.84$ & epeiric sea, open to the ocean & 13 & $+0.40 \pm 0.46$ & $-0.28 \pm 0.44$ & $+0.23 \pm 0.42$ \\
\hline \multirow{2}{*}{ Belt Spgp. } & \multirow{2}{*}{ USA } & \multirow{2}{*}{1.47} & intracontinental rift basin, possibly restricted, onshore & 8 & $+0.73 \pm 0.33$ & $-1.09 \pm 0.34$ & $-0.34 \pm 0.49$ \\
\hline & & & intracontinental rift basin, possibly restricted, offshore & 7 & $-0.07 \pm 0.43$ & $-0.75 \pm 0.39$ & $-0.49 \pm 0.62$ \\
\hline Roper Gp. & Australia & 1.36 & epeiric sea, open to the ocean, offshore & 7 & $+0.53 \pm 0.20$ & $-0.13 \pm 0.71$ & $-0.01 \pm 0.14$ \\
\hline El Mreiti Gp. & Mauritania & 1.10 & epeiric sea, open to the ocean, intermediate depth & 5 & $+0.45 \pm 0.52$ & $+0.58 \pm 0.69$ & $-0.14 \pm 0.70$ \\
\hline Stephen Fm. & Canada & 0.54 & open marine shelf, submarine fan & 1 & +0.96 & -1.11 & +0.23 \\
\hline Woodbend Gp. & Canada & 0.36 & epeiric sea, open to the ocean & 5 & $+0.04 \pm 0.47$ & $-0.27 \pm 0.86$ & $+0.21 \pm 0.46$ \\
\hline Wocklum Limestone & Germany & 0.34 & epeiric sea, open to the ocean & 2 & $-0.72 \pm 0.28$ & $-1.46 \pm 0.14$ & \\
\hline Phosphoria Fm. & USA & 0.26 & epeiric sea, open to the ocean & 3 & $+0.01 \pm 0.74$ & $-0.66 \pm 0.23$ & \\
\hline Peril/Sandilands Fm. & Canada & 0.20 & open marine shelf & 12 & $+0.23 \pm 0.34$ & $+0.64 \pm 0.45$ & $-0.79 \pm 0.48$ \\
\hline Fidalgo Complex & USA & 0.16 & deep open basin, turbidite ( preserved as ophiolite) & 1 & -0.29 & -0.36 & -0.50 \\
\hline Morrison Fm. & USA & 0.15 & interior seaway, possibly restricted & 1 & -1.20 & -1.05 & \\
\hline North Atlantic & Portugal & 0.12 & open marine margin, submarine fan & 8 & $-0.41 \pm 0.23$ & $+0.01 \pm 0.26$ & $-0.58 \pm 0.30$ \\
\hline Nanaimo Gp. & USA & 0.08 & open marine shelf, turbidite & 1 & +0.43 & -0.31 & -0.63 \\
\hline Mowry/Eagle/Cody Fm. & USA & $0.10-0.07$ & interior seaway, possibly restricted & 4 & $-0.44 \pm 0.65$ & $-0.53 \pm 0.22$ & $-1.20 \pm 0.13$ \\
\hline Hell Creek/Tullock Fm. & USA & 0.065 & fluvio-lacustrine & 4 & $+0.25 \pm 0.57$ & $-0.06 \pm 0.36$ & \\
\hline
\end{tabular}


704 Table 2: Long-term averages of individual data points from open marine basins.

\begin{tabular}{lccc}
\hline & $\boldsymbol{\delta}^{82 / 78}$ Se [\%o] & TSe [ppm] & S/Se [wt\%/pphs \\
\hline $\begin{array}{l}\text { mid-Archean } \\
(3.19-2.87 G y r)\end{array}$ & $+0.62 \pm 0.27$ & $10^{-0.76 \pm 0.21}$ & $10^{-0.31 \pm 0.36} 706$ \\
\hline $\begin{array}{l}\text { late Archean } \\
(2.71-2.50 G y r)\end{array}$ & $+0.35 \pm 0.39$ & $10^{0.16 \pm 0.46}$ & $10^{-0.12 \pm 0.59} 707$ \\
\hline $\begin{array}{l}\text { Proterozoic } \\
(2.49-1.10 G y r)\end{array}$ & $+0.45 \pm 0.55$ & $10^{-0.13 \pm 0.78}$ & $10^{-0.10 \pm 0.48}$ \\
\hline $\begin{array}{l}\text { Phanerozoic } \\
\text { (0.54Gyr to modern) }\end{array}$ & $-0.19 \pm 0.59$ & $10^{0.24 \pm 0.72}$ & $10^{-0.78 \pm 0.71}$ \\
\hline
\end{tabular}


714 Figure 1: Se isotopes in open and restricted marine basins over the last $500 \mathrm{kyr}$. The

715 compositions of the crust and the lower limit for the composition of seawater $\mathrm{Se} \mathrm{IV}^{\mathrm{IVI}}$ are shown

716 for reference (dashed black lines). Open marine sediments $(n=96)$ are systematically depleted

717 where as restricted basins $(\mathrm{n}=37)$ tend to preserve the composition of $\mathrm{Se}^{\mathrm{IV} / \mathrm{VI}}$, probably due to

718 more quantitative reduction. See text for references.

720 Figure 2: Mass-dependent fractionation in Se isotopes. a: $\delta^{82 / 76} \mathrm{Se}$ versus $\delta^{82 / 78} \mathrm{Se}$; b: $\delta^{82 / 77} \mathrm{Se}$

721 versus $\delta^{82 / 78} \mathrm{Se}$; c: $\delta^{78 / 74} \mathrm{Se}$ versus $\delta^{82 / 78} \mathrm{Se}$. One outlier with $\delta^{78 / 74} \mathrm{Se}=-13.7 \%$ is not shown.

722 Residual interferences are the most likely explanation for outliers in panels b and c. We therefore

723 conclude that all four isotope pairs display mass-dependent fractionation. Error bars are $1 \sigma$.

725 Figure 3: Whole-rock Se isotopes (a), abundances (b), and TS/TSe ratios (c) in mudrocks

726 through time. Horizontal lines mark the total marine average (solid) $\pm 1 \sigma$ (dashed) of new and

727 published data.

729 Figure 4: Se in selected basins. a: Witwatersrand Supergroup; b: Fortescue Group; c and d: Belt

730 Supergroup; e: Ghaap Group; f: Cretaceous Atlantic Ocean, where data from OAE-II are from

731 Mitchell et al.(2012). Error bars are $1 \sigma$. 
734 Figure 5: Total selenium (TSe) versus total sulfur (TS) and total organic carbon (TOC).

735 Correlations are significant in logarithmic scale (panels a and b) but not in linear scale (panel c 736 and d).

738 Figure 6: Proposed modern marine Se cycle. $\delta=\delta^{82 / 78}$ Se. Sources to the ocean include

739 continental and seafloor weathering, volcanic emissions and hydrothermal fluids with isotopic 740 compositions probably similar to that of the crust. Se oxyanions $\left(\mathrm{SeO}_{\mathrm{x}}{ }^{2-}\right.$, where $\mathrm{x}=3$ for $\mathrm{Se}^{\mathrm{IV}}$ or

7414 for $\mathrm{Se}^{\mathrm{VI}}$ ) sourced from weathering may be reduced non-quantitatively to $\mathrm{Se}^{0}$ or inorganic $\mathrm{Se}^{-\mathrm{II}}$

742 (FeSe) during diagenesis, leading to negative $\delta^{82 / 78}$ Se values in sediments under an oxic water

743 column. These negative values may be diluted with isotopically positive organic $\mathrm{Se}^{-\mathrm{II}}$ or $\mathrm{Se}^{\mathrm{IV}}$

744 adsorbed to FeMn-oxides $\left(\mathrm{FeMn}-\mathrm{SeO}_{3}\right)$. Reduction and/or assimilation into biomass are

745 quantitative in restricted anoxic basins. Emissions of dimethyl selenide (DMSe) have apparently

746 been negligible over geologic timescales. See text for references. 


\section{References}

Ader, M., Sansjofre, P., Halverson, G.P., Busigny, V., Trindade, R.I., Kunzmann, M. and Nogueira, A.C., 2014. Ocean redox structure across the Late Neoproterozoic Oxygenation Event: A nitrogen isotope perspective. Earth and Planetary Science Letters, 396: 1-13.

Anbar, A.D., 2004. Molybdenum stable isotopes: observations, interpretations and directions. Reviews in Mineralogy and Geochemistry, 55: 429-454.

Anbar, A.D., Duan, Y., Lyons, T.W., Arnold, G.L., Kendall, B., Creaser, R.A., Kaufmann, A.J., Gordon, G.W., Scott, C., Garvin, J. and Buick, R., 2007. A whiff of oxygen before the Great Oxidation Event? Science, 317: 1903-1906.

Bekker, A. and Holland, H.D., 2012. Oxygen overshoot and recovery during the early Paleoproterozoic. Earth and Planetary Science Letters, 317: 295-304.

Bekker, A., Holland, H.D., Wang, P.L., Rumble III., D., Stein, H.J., Hannah, J.L., Coetzee, L.L. and Beukes, N.J., 2004. Dating the rise of atmospheric oxygen. Nature, 427: 117-120.

Brookins, D.G., 1988. Eh-pH Diagrams for Geochemistry. Springer-Verlag, New York.

Buick, R., 1992. The antiquity of oxygenic photosynthesis: evidence from stromatolites in sulphate-deficient Archaean lakes. Science, 255: 74-77.

Buick, R., 2008. When did oxygenic photosynthesis evolve? Philosophical Transactions of the Royal Society B: Biological Sciences, 363: 2731-2743.

Canfield, D.E., Poulton, S.W., Knoll, A.H., Narbonne, G.M., Ross, G., Goldberg, T. and Strauss, H., 2008. Ferruginous conditions dominated later Neoproterozoic deep-water chemistry. Science, 321: 949-952.

Canfield, D.E., Poulton, S.W. and Narbonne, G.M., 2007. Late-Neoproterozoic deep-ocean oxygenation and the rise of animal life. Science, 315: 92-95.

Chasteen, T.G. and Bentley, R., 2003. Biomethylation of selenium and tellurium: microorganisms and plants. Chemical Reviews, 103: 1-26.

Clark, S.K. and Johnson, T.M., 2010. Selenium stable isotope investigation into selenium biogeochemical cycling in a lacustrine environment: Sweitzer Lake, Colorado. Journal of Environmental Quality, 39: 2200-2210.

Conde, J.E. and Alaejos, M.S., 1997. Selenium concentrations in natural and environmental waters. Chemical Reviews, 97: 1979-2003.

Crowe, S.A., Døssing, L.N., Beukes, N.J., Bau, M., Kruger, S.J., Frei, R. and Canfield, D.E., 2013. Atmospheric oxygenation three billion years ago. Nature, 501: 535-538.

Cutter, G.A., 1982. Selenium in reducing waters. Science, 217: 829-831.

Cutter, G.A., 1992. Kinetic controls on metalloid speciation in seawater. Marine Chemistry, 40: 65-80.

Cutter, G.A. and Bruland, K.W., 1984. The marine biogeochemistry of selenium: a re-evaluation. Limnology and Oceanography, 29: 1179-1192.

Cutter, G.A. and Cutter, L.S., 2001. Sources and cycling of selenium in the western and equatorial Atlantic Ocean. Deep-Sea Research II, 48: 2917-2931.

Doblin, M.A., Baines, S.B., Cutter, L.S. and Cutter, G.A., 2006. Sources and biogeochemical cycling of particulate selenium in the San Francisco Bay estuary. Estuarine, Coastal and Shelf Science, 67: 681-694.

Eigenbrode, J.L. and Freeman, K.H., 2006. Late Archean rise of aerobic microbial ecosystems. Proceedings of the National Academy of Sciences, 103: 15759-15764. 
Ellis, A.S., Johnson, T.M., Herbel, M.J. and Bullen, T., 2003. Stable isotope fractionation of selenium by natural microbial consortia. Chemical Geology, 195: 119-129.

Fan, H.F., Wen, H., Hu, M. and Zhao, H., 2011. Selenium speciation in Lower Cambrian Seenriched strata in South China and its geological implications. Geochimica et Cosmochimica Acta, 75: 7725-7740.

Farquhar, J., Bao, H. and Thiemens, M., 2000. Atmospheric influence on Earth's earliest sulfur cycle. Science, 289: 756-758.

Farquhar, J., Peters, M., Johnston, D.T., Strauss, H., Masterson, A., Wiechert, U. and Kaufman, A.J., 2007. Isotopic evidence for Mesoarchaean anoxia and changing atmospheric sulphur chemistry. Nature, 449: 706-709.

Flannery, D.T. and Walter, M.R., 2012. Archean tufted microbial mats and the Great Oxidation Event: new insights into an ancient problem. Australian Journal of Earth Sciences, 59: 111.

Frei, R., Gaucher, C., Poulton, S.W. and Canfield, D.E., 2009. Fluctuations in Precambrian atmospheric oxygenation recorded by chromium isotopes. Nature, 461: 250-253.

Garvin, J., Buick, R., Anbar, A.D., Arnold, G.L. and Kaufman, A.J., 2009. Isotopic evidence for an aerobic nitrogen cycle in the latest Archean. Science, 323: 1045-1048.

Gladyshev, V.N., 2012. Selenoproteins and selenoproteomes. In: D.L. Hatfield, M.J. Berry and V.N. Gladyshev (Editors), Selenium: Its molecular biology and role in human health. Springer Science + Business Media, pp. 109-123.

Godfrey, L.V. and Falkowski, P.G., 2009. The cycling and redox state of nitrogen in the Archaean ocean. Nature Geoscience, 2: 725-729.

Gosh, S., Xu, Y., Humayun, M. and Odom, L., 2008. Mass-dependent fractionation of mercury isotopes in the environment. Geochemistry Geophysics Geosystems, 9: doi:10.1029/2007GC001827.

Guy, B.M., Ono, S., Gutzmer, J., Kaufman, A.J., Lin, Y., Fogel, M.L. and Beukes, N.J., 2012. A multiple sulfur and organic carbon isotope record from non-conglomeratic sedimentary rocks of the Mesoarchean Witwatersrand Supergroup, South Africa. Precambrian Research, 216: 208-231.

Guy, B.M., Ono, S., Gutzmer, J., Lin, Y. and Beukes, N.J., 2014. Sulfur sources of sedimentary "buckshot" pyrite in the Auriferous Conglomerates of the Mesoarchean Witwatersrand and Ventersdorp Supergroups, Kaapvaal Craton, South Africa. Mineralium Deposita, 49: 751-775.

Hagiwara, Y., 2000. Selenium isotope ratios in marine sediments and algae: A reconnaissance study. M.Sc. Thesis, University of Illinois at Urbana-Champaign, Urbana, IL, 62 pp.

Hardisty, D.S., Lu, Z., Planavsky, N.J., Bekker, A., Philippot, P., Zhou, X. and Lyons, T.W., 2014. An iodine record of Paleoproterozoic surface ocean oxygenation. Geology: doi:10.1130/G35439.1.

Henderson, P. and Henderson, G.M., 2009. The Cambridge Handbook of Earth Science Data. Cambridge University Press, New York.

Herbel, M.J., Johnson, T.M., Oremland, R.S. and Bullen, T., 2000. Fractionation of selenium isotopes during bacterial respiratory reduction of selenium oxyanions. Geochimica et Cosmochimica Acta, 64: 3701-3709.

Johnson, T.M., 2004. A review of mass-dependent fractionation of selenium isotopes and implications for other heavy stable isotopes. Chemical Geology, 204: 201-214. 
Johnson, T.M. and Bullen, T., 2003. Selenium isotope fractionation during reduction by $\mathrm{Fe}(\mathrm{II})-$ Fe(III) hydroxide-sulfate (green rust). Geochimica et Cosmochimica Acta, 67: 413-419. Johnson, T.M. and Bullen, T., 2004. Mass-dependent fractionation of selenium and chromium isotopes in low-temperature environments. Reviews in Mineralogy and Geochemistry, 55: 289-317.

Johnson, T.M., Herbel, M.J., Bullen, T.D. and Zawislanski, P.T., 1999. Selenium isotope ratios as indicators of selenium sources and oxyanion reduction. Geochimica et Cosmochimica Acta, 63: 2775-2783.

Johnston, D.T., Poulton, S.W., Goldberg, T., Sergeev, V.N., Podkovyrov, V., Vorob'eva, N.G., Bekker, A. and Knoll, A.H., 2012. Late Ediacaran redox stability and metazoan evolution. Earth and Planetary Science Letters, 335: 25-35.

Kendall, B., Reinhard, C.T., Lyons, T.W., Kaufman, A.J., Poulton, S.W. and Anbar, A.D., 2010. Pervasive oxygenation along late Archaean ocean margins. Nature Geoscience, 3: 647652.

Krouse, H.R. and Thode, H.G., 1962. Thermodynamic properties and geochemistry of isotopic compounds of selenium. Canadian Journal of Chemistry, 40: 367-375.

Kulp, T.R. and Pratt, L.M., 2004. Speciation and weathering of selenium in Upper Cretaceous chalk and shale from South Dakota and Wyoming, USA. Geochimica et Cosmochimica Acta, 68: 3687-3701.

Lalonde, S.V. and Konhauser, K.O., 2015. Benthic perspective on Earth's oldest evidence for oxygenic photosynthesis. Proceedings of the National Academy of Sciences: doi: 10.1073/pnas.1415718112.

Large, R.R., Halpin, J.A., Danyushevsky, L.V., Maslennikov, V.V., Bull, S.W., Long, J.A., Gregory, D.D., Lounejeva, E., Lyons, T.W., Sack, P.J., McGoldrick, P. and Calver, C.R., 2014. Trace element content of sedimentary pyrite as a new proxy for deep-time oceanatmosphere evolution. Earth and Planetary Science Letters, 389: 209-220.

Layton-Matthews, D., Leybourne, M.I., Peter, J.M., Scott, S.D., Cousens, B. and Eglington, B., 2013. Multiple sources of selenium in ancient seafloor hydrothermal systems: compositional and $\mathrm{Se}, \mathrm{S}$ and $\mathrm{Pb}$ isotopic evidence from volcanic-hosted and volcanicsediment-hosted massive sulfide deposits of the Finlayson Lake District, Yukon, Canada. Geochimica et Cosmochimica Acta, 117: 313-331.

Li, X. and Liu, Y., 2011. Equilibrium Se isotope fractionation parameters: A first principle study. Earth and Planetary Science Letters, 304: 113-120.

Lyons, T.W., Reinhard, C.T. and Planavsky, N.J., 2014a. The rise of oxygen in Earth's early ocean and atmosphere. Nature, 506: 307-315.

Lyons, T.W., Reinhard, C.T. and Planavsky, N.J., 2014b. The rise of oxygen in Earth's early ocean and atmosphere. Nature, 506: 307-315.

Mayland, H.F., 1994. Selenium in plant and animal nutrition. In: W.T. Frankenberger Jr. and S. Benson (Editors), Selenium in the environment. Marcel Dekker, Inc., New York.

Mitchell, K., Couture, R.M., Johnson, T.M., Mason, P.R. and Van Cappellen, P., 2013. Selenium sorption and isotope fractionation: Iron (III) oxides versus iron (II) sulfides. Chemical Geology, 342: 21-28.

Mitchell, K., Mason, P.R.D., Van Cappellen, P., Johnson, T.M., Gill, B.C., Owens, J.D., Ingall, E.D., Reichart, G.-J. and Lyons, T.W., 2012. Selenium as paleo-oceanographic proxy: A first assessment. Geochimica et Cosmochimica Acta, 89: 302-317. 
Mosher, B.W. and Duce, R.A., 1987. A global atmospheric selenium budget. Journal of Geophysical Research, 92: 13289-13298.

Planavsky, N.J., Asael, D., Hofmann, A., Reinhard, C.T., Lalonde, S.V., Knudsen, A., Wang, X., Ossa Ossa, F., Pecoits, E., Smith, A.J.B., Beukes, N.J., Bekker, A., Johnson, T.M., Konhauser, K.O., Lyons, T.W. and Rouxel, O.J., 2014a. Evidence for oxygenic photosynthesis half a billion years before the Great Oxidation Event. Nature Geoscience, 7: 283-286.

Planavsky, N.J., Bekker, A., Hofmann, A., Owens, J.D. and Lyons, T.W., 2012. Sulfur record of rising and falling marine oxygen and sulfate levels during the Lomagundi event. Proceedings of the National Academy of Sciences, 109: 18300-18305.

Planavsky, N.J., Reinhard, C.T., Wang, X., Thomson, D., McGoldrick, P., Rainbird, R.H., Johnson, T., Fischer, W.W. and Lyons, T.W., 2014b. Low Mid-Proterozoic atmospheric oxygen levels and the delayed rise of animals. Science, 346: 635-638.

Pogge von Strandmann, P., Coath, C.D., Catling, D.C., Poulton, S. and Elliott, T., 2014. Analysis of mass dependent and mass independent selenium isotope variability in black shales. Journal of Analytical Atomic Spectrometry, 29: 1648-1659.

Poulton, S.W. and Canfield, D.E., 2011. Ferruginous conditions: a dominant feature of the ocean through Earth's history. Elements, 7: 107-112.

Rashid, K. and Krouse, H.R., 1985. Selenium isotopic fractionation during $\mathrm{SeO}_{3}$ reduction to $\mathrm{Se}^{0}$ and $\mathrm{H}_{2}$ Se. Canadian Journal of Chemistry, 63: 3195-3199.

Rasmussen, B. and Buick, R., 1999. Redox state of the Archean atmosphere: Evidence from detrital heavy minerals in ca. 3250-2750 Ma sandstones from the Pilbara Craton, Australia. Geology, 27: 115-118.

Rees, C.E. and Thode, H.G., 1966. Selenium isotope effects in the reduction of sodium selenite and of sodium selenate. Canadian Journal of Chemistry, 44: 419-427.

Reinhard, C.T., Lalonde, S.V. and Lyons, T.W., 2013a. Oxidative sulfide dissolution on the early Earth. Chemical Geology, 362: 44-55.

Reinhard, C.T., Planavsky, N.J., Robbins, L.J., Partin, C.A., Gill, B.C., Lalonde, S.V., Bekker, A., Konhauser, K.O. and Lyons, T.W., 2013b. Proterozoic ocean redox and biogeochemical stasis. Proceedings of the National Academy of Sciences, 110: 53575362.

Ross, G.M. and Villeneuce, M., 2003. Provenance of the Mesoproterozoic (1.45 Ga) Belt basin (western North America): another piece in the pre-Rodinia paleogeographic puzzle. Geological Society of America Bulletin, 115: 1191-1217.

Rouxel, O., Fouquet, Y. and Ludden, J.N., 2004. Subsurface processes at the Lucky Strike hydrothermal field, Mid-Atlantic Ridge: evidence from sulfur, selenium, and iron isotopes. Geochimica et Cosmochimica Acta, 68: 2295-2311.

Rouxel, O., Ludden, J., Carignan, J., Marin, L. and Fouquet, Y., 2002. Natural variations of Se isotopic composition determined by hydride generation multiple collector inductively coupled plasma mass spectrometry. Geochimica et Cosmochimica Acta, 66: 3191-3199.

Rubin, K., 1997. Degassing of metals and metalloids from erupting seamount and mid-ocean ridge volcanoes: observations and predictions. Geochimica et Cosmochimica Acta, 61: 3525-3542.

Rudnick, R.L. and Gao, S., 2014. Composition of the continental crust. Treatise on Geochemistry, 4: 1-51. 
Sahoo, S.K., Planavsky, N.J., Kendall, B., Wang, X., Shi, X., Scott, C., Anbar, A.D., Lyons, T.W. and Jiang, G., 2012. Ocean oxygenation in the wake of the Marinoan glaciation. Nature, 489: 546-549.

Schilling, K., Basu, A., Johnson, T.M., Mason, P.R.D., Tsikos, H. and Mondal, S.K., 2014a. Se isotope signature of Paleoarchean and Paleoproterozoic banded iron formations, Goldschmidt Conference Abstract \# 2207, Sacramento, CA, USA.

Schilling, K., Johnson, T.M. and Mason, P.R.D., 2014b. A sequential extraction technique for mass-balanced stable selenium isotope analysis of soil samples. Chemical Geology, 381: 125-130.

Schilling, K., Johnson, T.M. and Wilcke, W., 2011a. Isotope fractionation of selenium during fungal biomethylation by Alternaria alternate. Environmental Science and Technology, 45: 2670-2676.

Schilling, K., Johnson, T.M. and Wilcke, W., 2011b. Selenium partitioning and stable isotope ratios in urban topsoil. Soil Science Society of America Journal, 75: 1354-1364.

Schirmer, T., Koschinsky, A. and Bau, M., 2014. The ratio of tellurium and selenium in geological material as a possible paleo-redox prox. Chemical Geology, 376: 44-51.

Schoepfer, S.D., Henderson, C.M., Garrison, G.H., Foriel, J., Ward, P.D., Selby, D., Hower, J.C., Algeo, T.J. and Shen, Y., 2013. Termination of a continent-margin upwelling system at the Permian-Triassic boundary (Opal Creek, Alberta, Canada). Global and Planetary Change, 105: 21-35.

Scott, C., Wing, B.A., Bekker, A., Planavsky, N.J., Medvedev, P., Bates, S.M., Yun, M. and Lyons, T.W., 2014. Pyrite multiple-sulfur isotope evidence for rapid expansion and contraction of the early Paleoproterozoic seawater sulfate reservoir. Earth and Planetary Science Letters, 389: 95-104.

Shields-Zhou, G. and Och, L., 2011. The case for a Neoproterozoic Oxygenation Event: Geochemical evidence and biological consequences. GSA Today, 21: 4-11.

Shore, A.J.T., 2010. Selenium geochemistry and isotopic composition of sediments from the Cariaco Basin and the Bermuda Rise: a comparison between a restricted basin and the open ocean over the last $500 \mathrm{ka}$. Ph.D. Thesis, University of Leicester, Leicester, $307 \mathrm{pp}$.

Siebert, C., McManus, J., Bice, A., Poulson, R. and Berelson, W.M., 2006. Molybdenum isotope signatures in continental margin marine sediments. Earth and Planetary Science Letters, 241: 723-733.

Stuieken, E.E., 2013. A test of the nitrogen-limitation hypothesis for retarded eukaryote radiation: Nitrogen isotopes across a Mesoproterozoic basinal profile. Geochimica et Cosmochimica Acta, 120: 121-139.

Stïeken, E.E., Buick, R. and Anbar, A.D., 2015. Selenium isotopes support free $\mathrm{O}_{2}$ in the latest Archean Geology, 43: 259-262.

Stüeken, E.E., Catling, D.C. and Buick, R., 2012. Contributions to late Archaean sulphur cycling by life on land. Nature Geoscience, 5: 722-725.

Stüeken, E.E., Foriel, J., Buick, R. and Schoepfer, S.D., submitted. Selenium isotope evidence for declining productivity under oxic conditions before the end-Permian mass extinction.

Stuieken, E.E., Foriel, J., Nelson, B.K., Buick, R. and Catling, D.C., 2013. Selenium isotope analysis of organic-rich shales: advances in sample preparation and isobaric interference correction. Journal of Analytical Atomic Spectrometry, 28: 1734-1749. 
973 Suzuoki, T., 1965. A geochemical study of selenium in volcanic exhalation and sulfur deposits.

974 II. On the behavior of selenium and sulfur in volcanic exhalation and sulfur deposits.

975 Bulletin of the Chemical Society of Japan, 38: 1940-1946.

976 Wen, H. and Carignan, J., 2007. Reviews on atmospheric selenium: Emissions, speciation and

977 fate. Atmospheric Environment, 41: 7151-7165.

978 Wen, H., Carignan, J., Chu, X., Fan, H., Cloquet, C., Huang, J., Zhang, Y. and Chang, H., 2014.

979 Selenium isotopes trace anoxic and ferruginous seawater conditions in the Early

980 Cambrian. Chemical Geology, 390: 164-172.

981 Wille, M., Kramers, J.D., Nägler, T.F., Beukes, N.J., Schröder, S., Meisel, T., Lacassie, J.P. and

982 Voegelin, A.R., 2007. Evidence for a gradual rise of oxygen between 2.6 and $2.5 \mathrm{Ga}$ from

983 Mo isotopes and Re-PGE signatures in shales. Geochimica et Cosmochimica Acta, 71:

984 2417-2435.

985 Zhu, J.M., Johnson, T.M., Clark, S.K., Zhu, X.K. and Wang, X.L., 2014. Selenium redox cycling during weathering of Se-rich shales: A selenium isotope study. Geochimica et Cosmochimica Acta, 126: 228-249.

991

Zingaro, R.A., Dufner, C.D., Murphy, A.P. and Moody, C.D., 1997. Reduction of oxoselenium anions by iron (II) hydroxide. Environment International, 23: 299-304. 


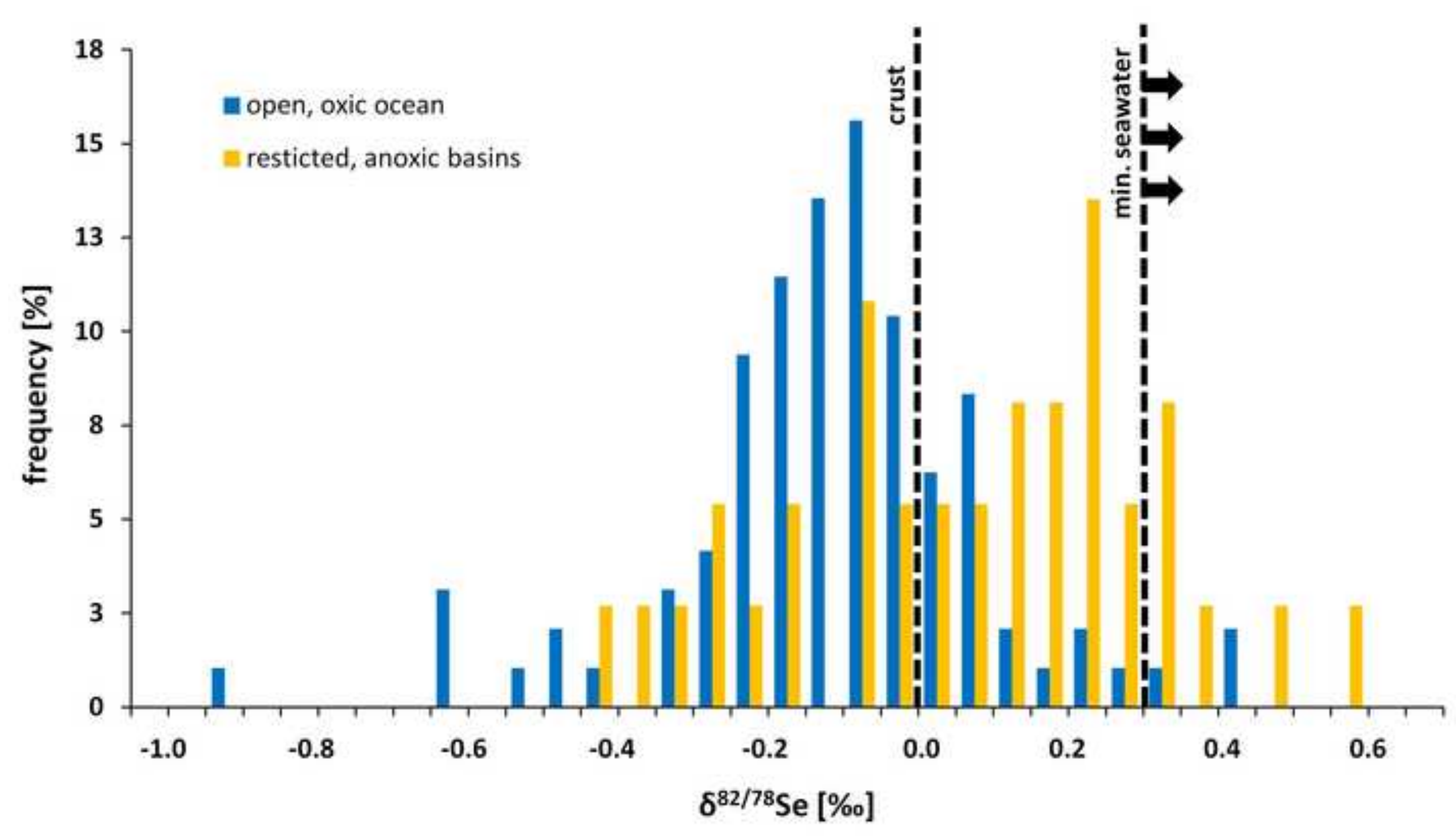



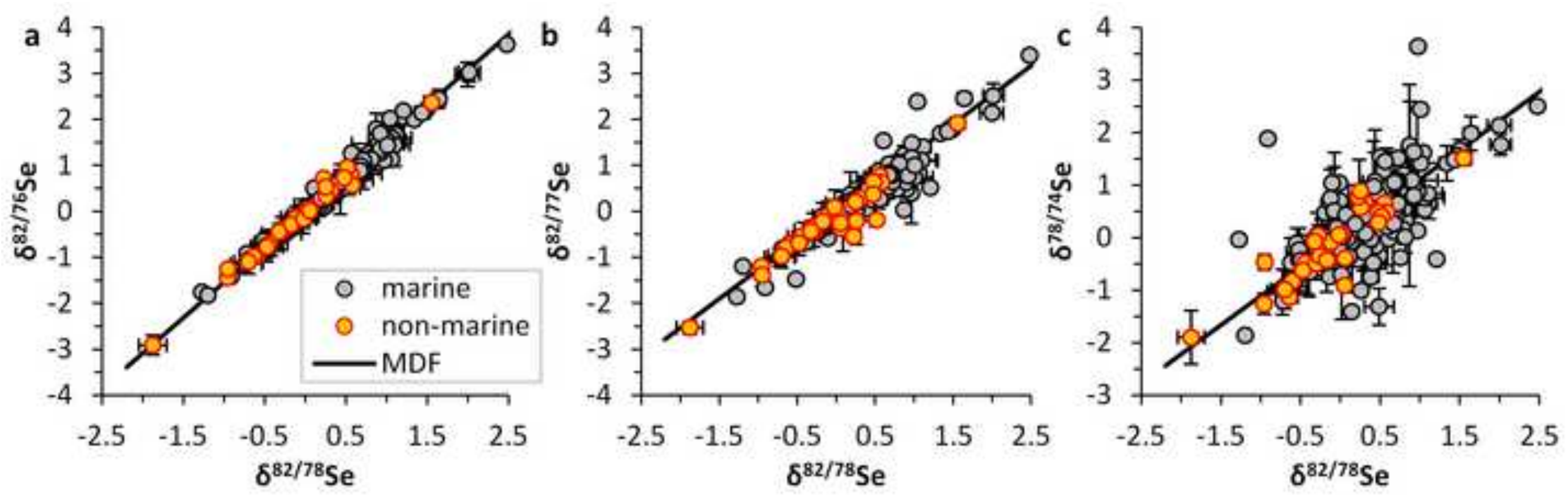
a

$x$ marine, published $\quad$ o marine, this study

onon-marine, this study + restricted, published
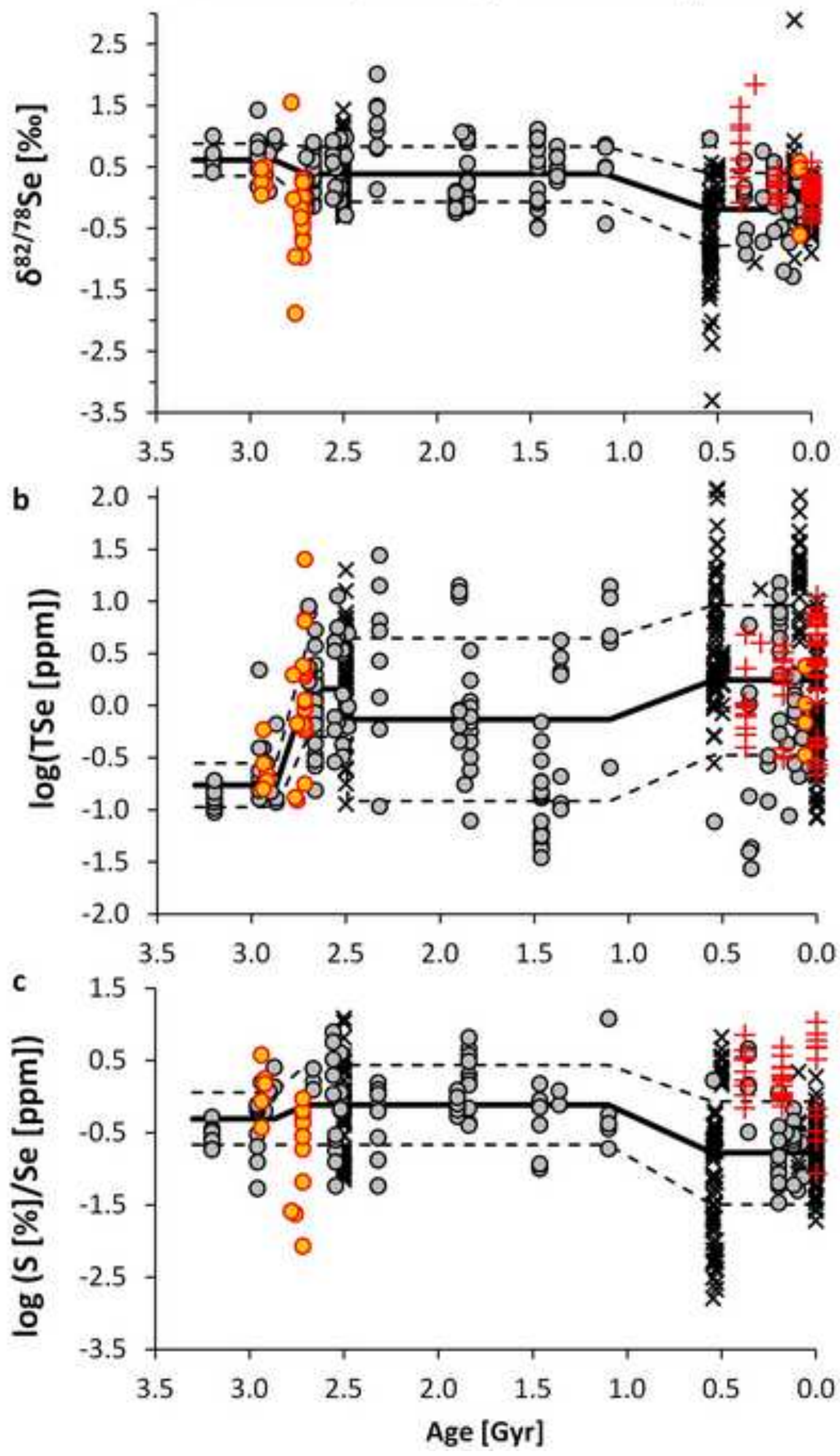
a. Witwatersrand Supergroup
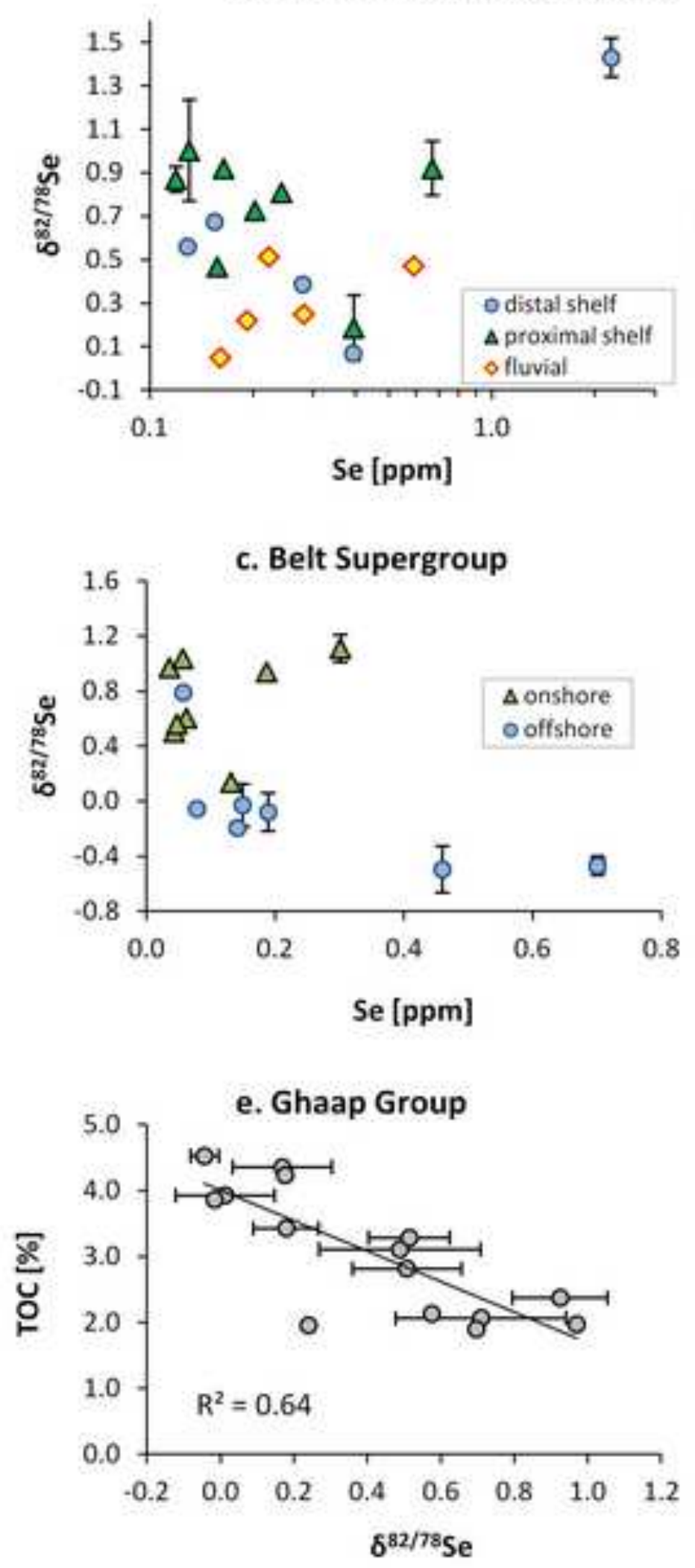

\section{b. Fortescue Group}
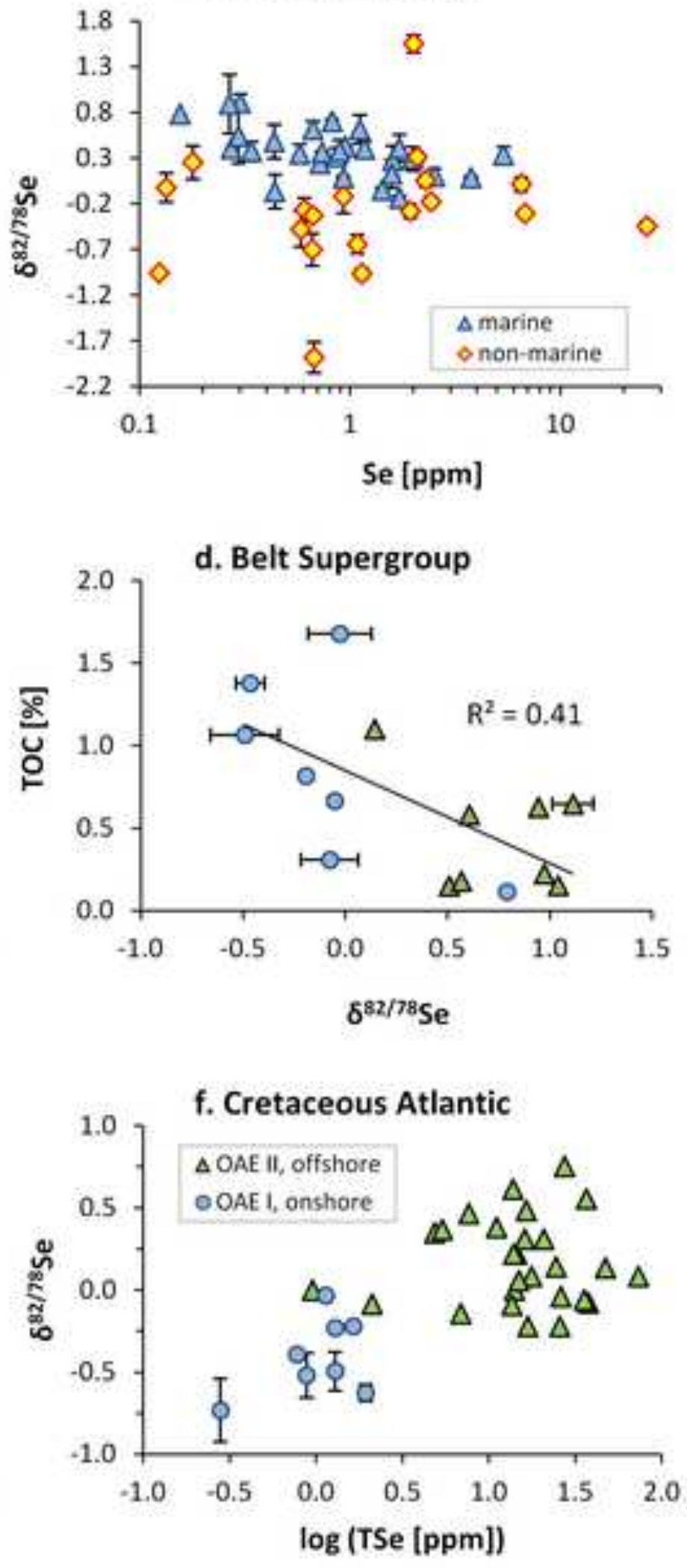


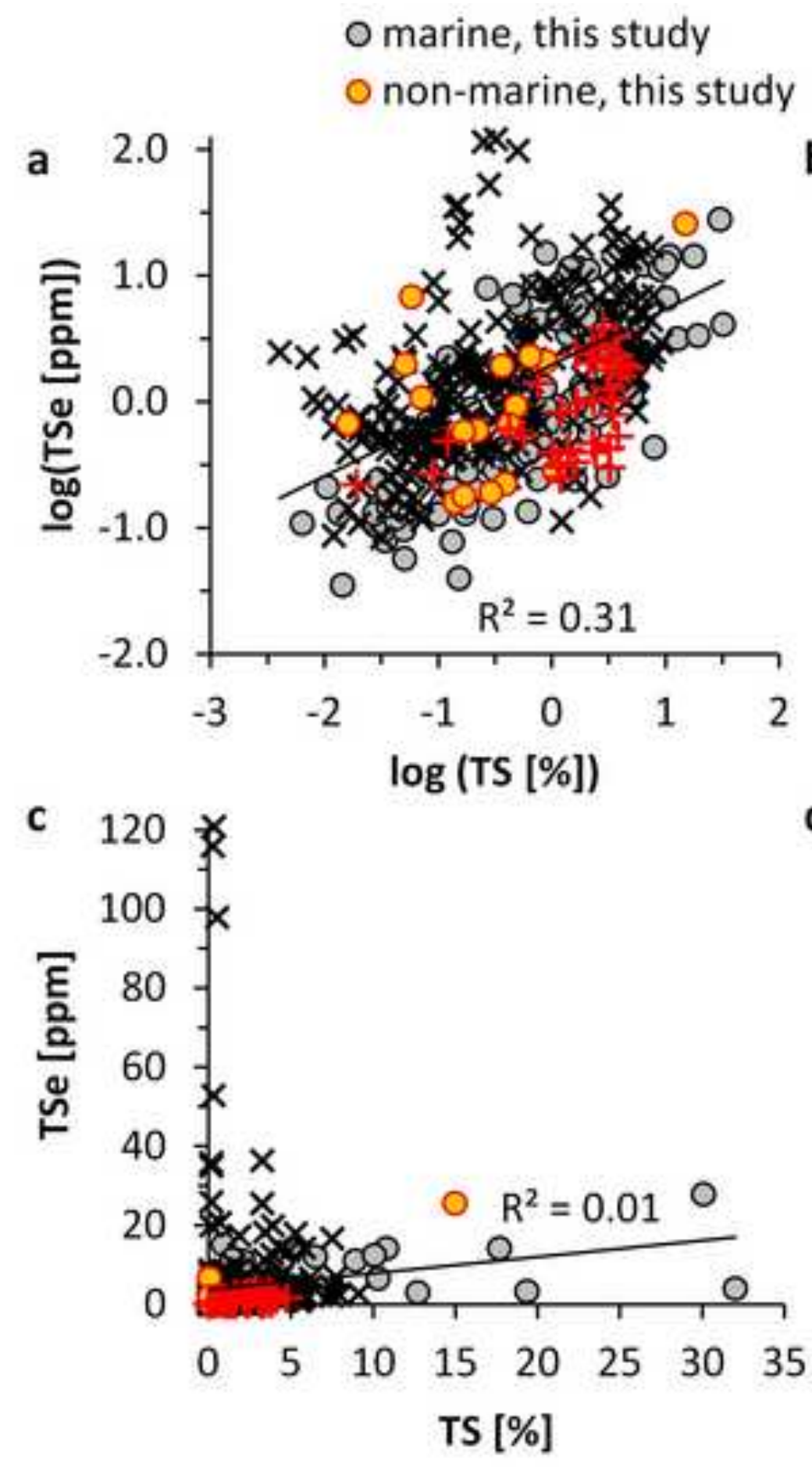

$x$ marine, published

+ restricted, published
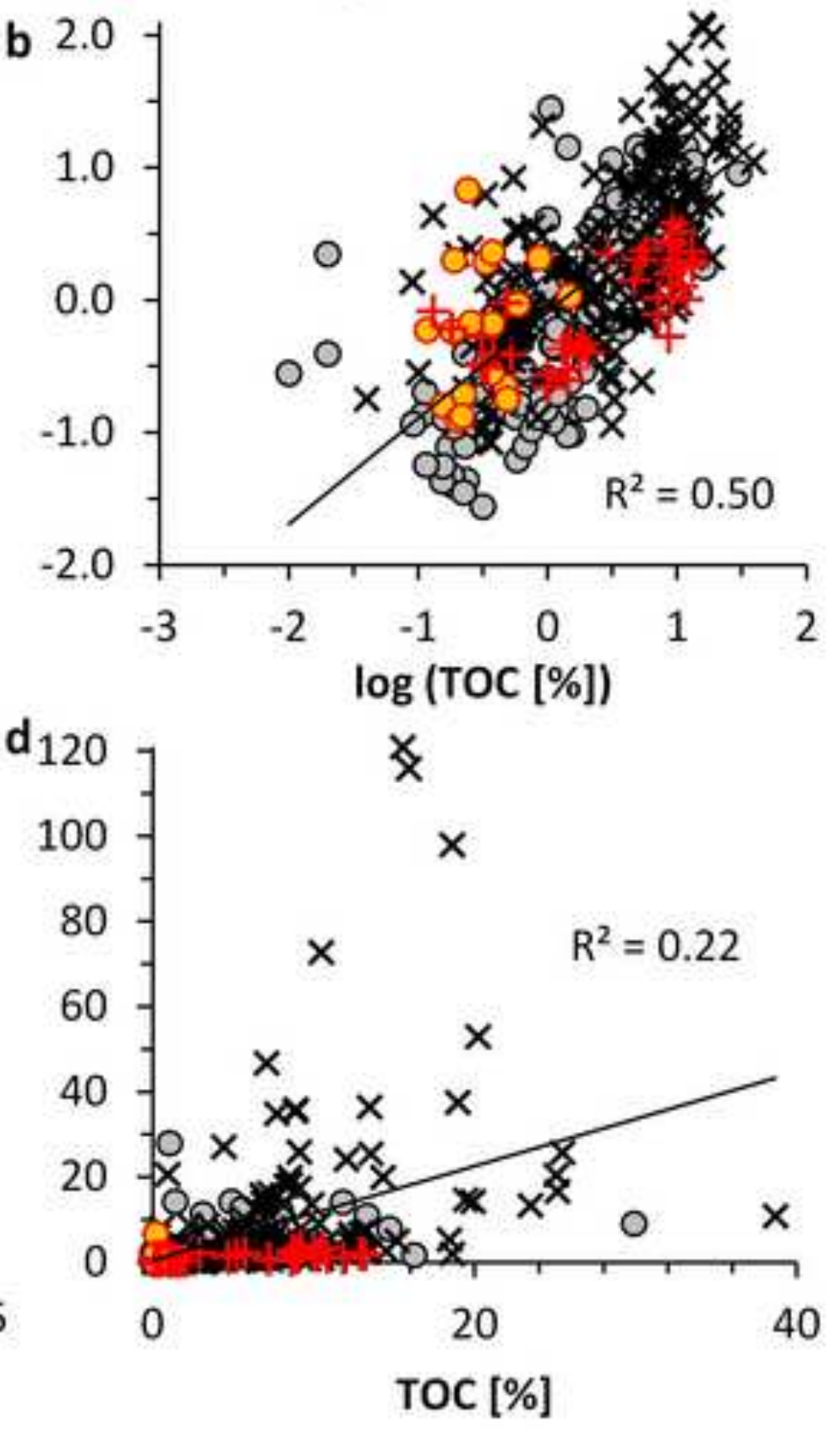


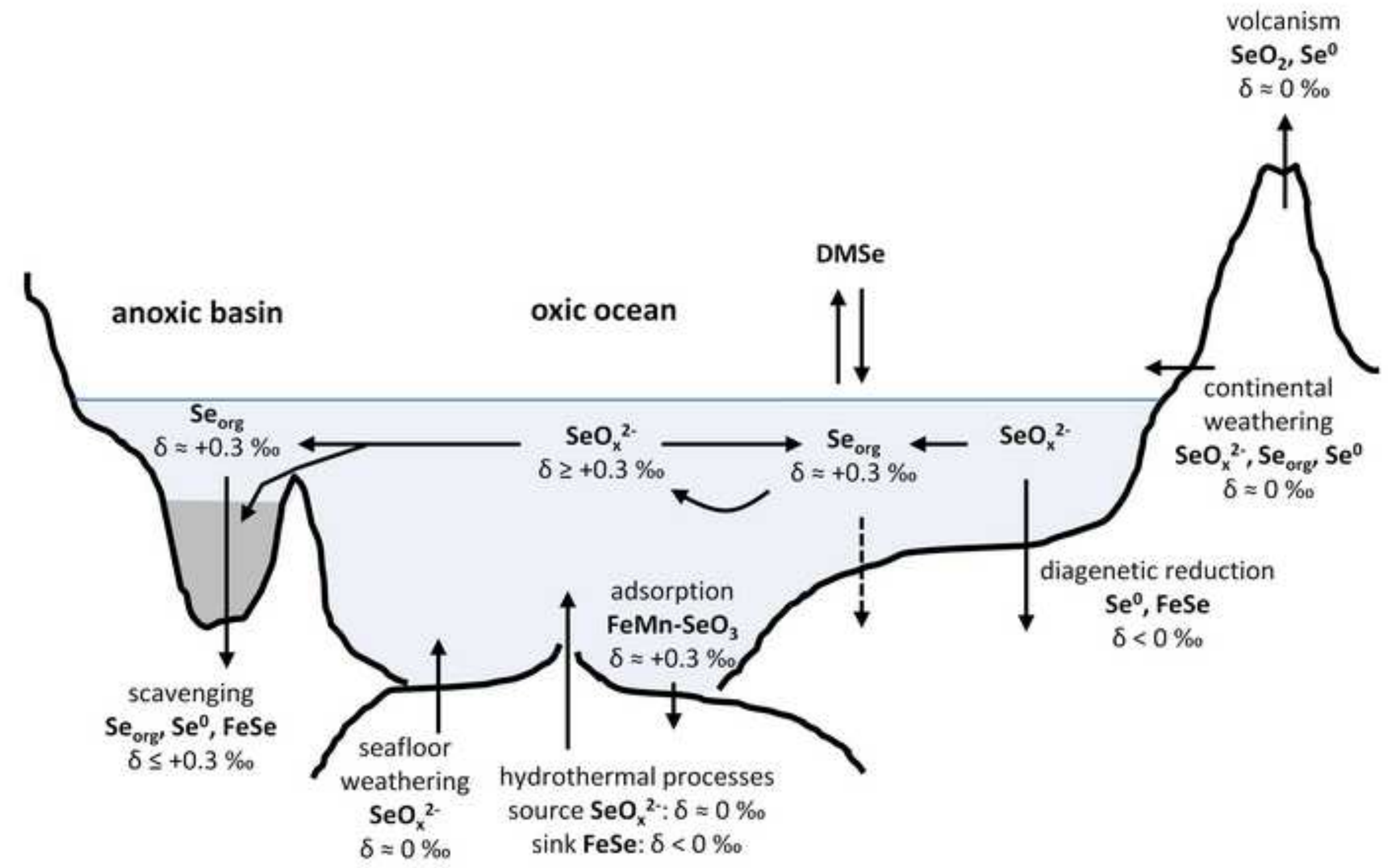

